\title{
CIENCIA Y MORAL: ELIANO DESDE ARISTÓTELES Y A LA LUZ DEL ESTOICISMO Y LA “ZOOFILIA” MODERNA *
}

MANUELA GARCÍA VALDÉS

Universidad de Oviedo. España

Se estudia De natura animalium de Eliano bajo la influencia recibida, principalmente, de la doctrina de Aristóteles en sus obras de biología y ética así como de la de los Estoicos. En ese marco ideológico se analizan con detalle las cualidades morales de los irracionales en la obra griega. La autora presenta, finalmente, una comparación de la postura de Eliano acerca de la consideración moral de los animales con la de algunos autores modernos y contemporáneos.

Palabras-clave: Ciencia y moral en Eliano; De natura animalium: ciencia y moral; de Aristóteles y Estoicos a Eliano: ciencia y moral; la consideración moral de los animales: en Eliano y en algunos autores modernos y contemporáneos
This paper is a study of the De natura animalium of Aelian under the influence received, mainly, from the Aristotle in his biological and ethics works as well as from the Stoics. In this ideological setting the author analyses in detail the moral qualities of the irrational beings in the Aelian's work. The investigation ends with a comparison about moral consideration of animals between the propositions of Aelian and the modern and contemporary authors.

Keywords: Science and moral in Aelian; De natura animalium: science and moral; from the Aristotle and Stoics to Aelian: science and moral; the moral consideration of the animals: in Aelian and in some modern and contemporary authors.

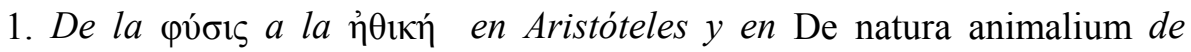
Eliano.

Eliano polemiza (NA VI 50) con la tesis de Hesíodo, cuando el poeta afirma que los dioses delimitaron las fronteras entre las diferentes especies de animales y sólo dieron a los hombres la capacidad de actuar con justicia ${ }^{1}$.

* Queremos expresar nuestro agradecimiento a la DGICYT (PB98-1569).

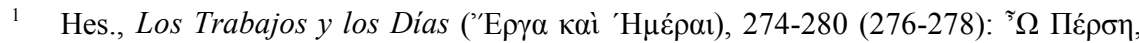

EMERITA. Revista de Lingüística y Filología Clásica (EM) — LXXI 1, 2003

pp. $1-50$ 
Eliano coincide en la cita hesiódica con Plutarco ${ }^{2}$, no parece, por tanto, una creación suya, sino procede, con gran probabilidad, de una fuente común para ambos. No obstante, Eliano la hace suya muy convencido y, a modo de confirmación, compara el proceder de las hormigas hacia el cadáver de una de ellas con la actuación de Príamo para rescatar el cuerpo sin vida de su hijo Héctor de las manos de Aquiles.

Hesíodo ante las amargas experiencias personales que debió de afrontar a causa de los venales jueces y los pleitos contra su hermano Perses, amonesta a éste para que haga imperar en su corazón la justicia. En medio de la situación personal que vive, profundiza en su idea del derecho que para él es la justicia de Zeus; es decir, el orden inalterable y absoluto, que cuida de que los buenos reciban su recompensa y los malos su castigo. No hay duda para Hesíodo: hay un mundo animal, el de la violencia, y un mundo del derecho, el mundo humano. Aunque bien sabe por experiencia que la separación no se da tan clara en la práctica de la vida de los hombres.

Eliano, que también muestra su ánimo desesperanzado, por las circunstancias generales en el aspecto social y político, de decadencia moral de su época, sin embargo, no comparte con Hesíodo esa separación entre los animales y los seres humanos. Precisamente de la Naturaleza quiere recuperar la Moral. En el inmenso material zoológico que ofrece - su obra Sobre la naturaleza de los animales consta de diecisiete libros -, figura una directriz primordial, arraigada en la corriente filosófica del estoicismo: mostrar el perfecto comportamiento del mundo animal al cumplir éste de manera exacta sus fines, conducta ejemplar, según Eliano, para los seres humanos.

Dedicaremos una atención especial en este apartado a la justificación teórica de esas interrelaciones, que son las que mejor muestran las coordenadas básicas de su pensamiento.

Otros griegos, a los que les dedicaremos atención posteriormente, le precedieron en esa postura; solo mencionaré, por ser el primero, a Homero,

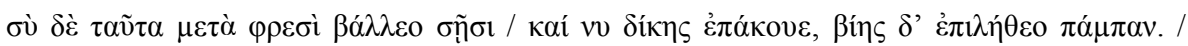

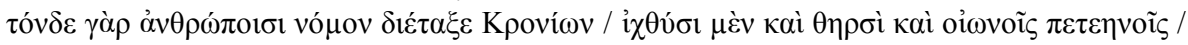

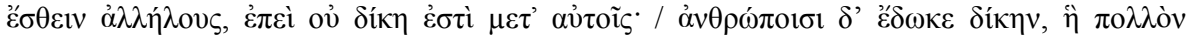

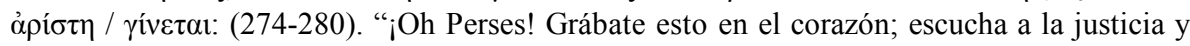
olvídate por entero de la violencia. Pues esta ley dispuso a los hombres el hijo de Crono: a los peces, a las fieras y a las aves voladoras, comerse los unos a los otros, ya que no existe justicia entre ellos, a los hombres, en cambio, les dio la justicia que es mejor con mucho".

2 Cf. Plu., Sobre el ingenio de los animales (De sollertia animalium) 964 B. 
muy citado por Eliano, más en la Ilíada que en la Odisea. En sus poemas épicos, de manera principal en las comparaciones frecuentes que presenta, los animales aparecen dotados de cualidades similares, o superiores, a las de los seres humanos, y dignas de ser imitadas. En estos poemas se encuentra una primera configuración del comportamiento humano; imperan los principios de una sociedad dominada por la tensión bélica; los héroes que destacan están marcados por los impulsos que promueve una sociedad

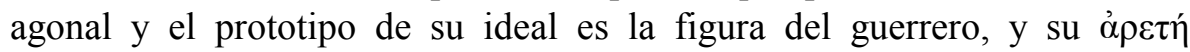
principal es el valor, por encima de la justicia; valor que es garantía del éxito; el héroe humano Sarpedón "avanza como un león montaraz" 3 . El $\tilde{\eta} \theta$ os, como dice Lledó ${ }^{4}$, no brota de la reflexión, del pensamiento que interpreta la experiencia, sino que se solidifica en las obras y en la actividad de los hombres. Es una organización práctica, una sociedad dinámica en la que se anticipa también aquello que formulará la primera teoría ética: "somos lo que hacemos", y admiramos al que posee esa virtud que se valora socialmente, en la homérica, como dijimos, el valor guerrero ${ }^{5}$. Sin embargo, en estos poemas se está abriendo ya paso, con dificultad, un nuevo estadio de evolución ${ }^{6}$, camino de una ética social e incluso de una ética de la intimidad, que pretenderá establecer en el hombre mismo y en su conciencia la causa y motor de sus obras; pero esta norma traspasa los confines de la ética homérica; esta ética está en el extremo opuesto, será la ética de los estoicos y de los epicúreos. El concepto de justicia ha recorrido, para ese

3 Cf., Hom., Il. XII 299-306. Entre numerosos trabajos, véase, en un resumen, el capítulo de J. Sánchez Lasso de la Vega, «Ética homérica», en Introducción a Homero, Madrid, 1963, pp. 291-316.

4 E. Lledó, «El mundo homérico», en Historia de la ética, I, ed. por Victoria Camps, Barcelona, pp. 15-34.

5 Aristóteles, EN II $1103 \mathrm{~b} 26 \mathrm{ss}$.

6 Cf., Hom., Il. XXIV 33-54 Es el pasaje en que Aquiles arrastra el cadáver de Héctor, el protegido de Apolo, en torno a la tumba de Patroclo, ante la impasibilidad de los dioses. Entonces Apolo, como si no saliese de la boca de un dios, toma la palabra y hace un reproche a los dioses y a la actuación de Aquiles, "Pero preferís favorecer al maldito Aquiles, que no tiene mientes sensatas ni pensamiento flexible en el pecho, que sólo conoce ferocidades, cual león que dejándose llevar por su enorme fuerza y su arrogante ánimo ataca los ganados de los mortales para darse un banquete. Así Aquiles perdió la piedad ('́̉ $\lambda \_\varsigma$ ) y también el respeto ( $\alpha i \delta \omega ́ c)$ ). (...) Eso no es lo mejor para él (...).”. Tomamos el pasaje como uno de los primeros documentos de la ética europea, de la Introducción de E. Lledó Iñigo - donde cita a F. Dirlmeier -, en Aristóteles. Ética Nicomáquea. Ética Eudemia, trad. por J. Pallí Bonet, ed. Gredos, Madrid, 1988, pp. 30-39. 
tiempo, un gran camino, desde los poemas homéricos y Hesíodo hasta el s. II d. C. La ley que debe regir y ser guía de la actuación de los hombres, en este siglo II, es el lógos divino que está impreso en la Naturaleza, en todos los seres tanto en los seres humanos como en el resto de los animales.

El objetivo de Eliano, en sentido amplio, es mostrar, de manera bastante semejante a la doctrina estoica, la sabiduría que hay en la Naturaleza ( $\varphi v ́ \sigma ı \varsigma)$. Ese insistir en la contraposición entre los animales y los humanos con la ventaja de los animales, parece debido también a que persisten motivos de la escuela cínica. Es conocida la conexión que hay entre la Estoa y la doctrina de Antístenes ${ }^{7}$; esto merecería un estudio más profundo que sólo tocaremos posteriormente. Querría detenerme en el que se podría considerar influjo básico aunque menos inmediato, en el científico y moralista prenestino; me refiero a la doctrina de Aristóteles de sus obras de biología y éticas - si bien esta doctrina hunde sus raíces en la filosofía platónica. Considero que esta doctrina científico-filosófica es un punto de partida conveniente para valorar de manera más profunda la actitud moralizadora de Eliano, dentro de la trayectoria del pensamiento griego, es decir, para comprender su pensamiento unido a una tradición filosófica platónico-aristotélica y de modo más inmediato a las doctrinas filosóficas del helenismo, y, principalmente, dentro de éstas al estoicismo; doctrina esta, que en su formulación tardía, nos introduce en la sociedad grecoromana de la época imperial, que atañe de manera más directa a nuestro autor. Eliano entronca, sin duda, con la doctrina platónico-aristotélica, tamizada por la impronta innegable del estoicismo romano. La compasiva sabiduría de Aristóteles sobre los seres vivos parece estar presente en la orientación moral que da Eliano a su investigación ${ }^{8}$. El enfoque que Eliano

\footnotetext{
7 Véase el capítulo «Los cínicos», en La filosofia helenística: éticas y sistemas, por C. García Gual, Ma J. Imaz, Madrid, 1986, pp 40-52.

8 Teofrasto, discípulo continuador del método y doctrina aritotélica, escribió un tratado Sobre la piedad (De pietate), que no ha llegado a nosotros; se conocen fragmentos citados por Porfirio en De abstinentia (3, 5). Sobre el principio nuevo de Aristóteles en la historia de la ética griega consistente en el análisis del acto moral, de la decisión moral misma, cf. la

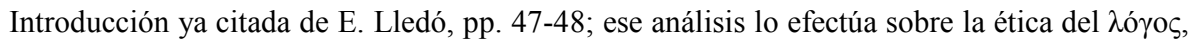
en ese nivel intermedio en que el hombre se homogeneiza con los demás animales, en el que "el $\lambda$ ó yos no funciona sólo como simple racionalidad, sino que está atravesado de impulsos, de pasiones y de deseos". En cuanto al origen de la Física aristotélica así como el de la Física estoica habría que remontarse al Timeo y al libro X de Las Leyes de Platón; cf., entre otros, sobre este aspecto, de manera breve, C. García Gual, M ${ }^{\mathrm{a}}$ J. Imaz, La filosofía helenística.
} 
imprime al material animal se puede comprender, por una parte, como respuesta a las explicaciones filosóficas de la acción de los seres humanos y de los demás animales, y, por otra, dentro del marco ideológico, social y político de su época.

Parece razonable considerar, como un sustrato del pensamiento de Eliano, el planteamiento de Aristóteles sobre la acción humana encuadrada en una investigación más amplia sobre el movimiento de los animales ${ }^{9}$. Son obras interesantes en estos aspectos, aparte de las Éticas, Sobre el movimiento de los animales (De motu) y Sobre el alma (De anima), en las que presenta una visión del ser humano dentro del reino animal y no como un ser separado de la Naturaleza.

Conviene decir previamente que la concepción aristotélica de Naturaleza

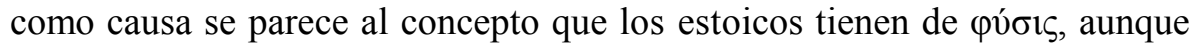
el Estagirita no confunde la Naturaleza con Dios ni la considera agente ra-

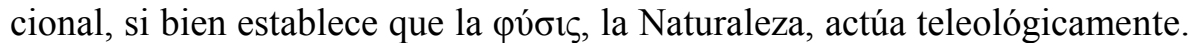
Para él, Dios es "acto puro", es el "primer motor inmóvil", y actúa sobre el mundo, pero no se confunde con la Naturaleza ${ }^{10}$. En cambio, el Lógos estoico (la recta Razón, la Providencia) tiene, más bien, sus precedentes en la anterior formulación platónica del "Alma del mundo" y del Demiurgo en el Timeo $^{11}$.

Dentro de la ingente bibliografía sobre la Ética y las éticas de Aristóteles, me han interesado, entre otros, los estudios de Martha Nussbaum por sus inteligentes planteamientos $\mathrm{y}$, de manera especial, por incidir en el tema que nos ocupa; aquéllos en que relaciona la acción humana y el movimiento de los seres vivos en general. En este aspecto, la seguiré de cerca ya que ofrece una visión coherente de la interrelación, en

Éticas y sistemas, ob. cit., pp. 132-171. A. López Eire, Diógenes Laercio. Los filósofos estoicos, ed. bilingüe, Barcelona, 1990; Introducción, pp. 40-46; seguiré esta edición para los textos estoicos.

9 Una síntesis útil de la ética griega, en un sentido general, plasmada en aportaciones de varios autores, se ofrece en Historia de la ética, 3 vols., ed. por V. Camps, en el vol. I, pp. 15-281, con bibliografía pertinente; cf., asimismo, F. Rodríguez Adrados, «La ética griega desde sus comienzos a su elaboración por los sofistas y Platón», Rev. de Occidente 35, 1984, pp. 23-47.

10 Cf., el estudio de Aristóteles sobre la filosofía primera en Metafisica.

11 Cf., Pl., Ti., 34 b-40c; 42 e. Cf. Introducción a la traducción del Timeo, en Platón. Diálogos, VI, Madrid, 1992, por F. Lisi, con bibliografía útil. 
Aristóteles, entre el movimiento de los seres vivientes y el deseo, y el de la Naturaleza y la Ética ${ }^{12}$. Enfoque que me parece pertinente como planteamiento previo para llegar al estoicismo romano y al pensamiento filosófico-moral de Eliano en su obra sobre los animales.

Antes de Aristóteles se puede decir que había dos modelos de explicación del movimiento animal. Uno, elaborado por la influyente tradición de la ciencia natural materialista (Diógenes de Apolonia, Demócrito con los atomistas). El segundo, es el modelo platónico que hiperintelectualiza las acciones racionales ${ }^{13}$; precisamente esta concepción intelectualista contribuye, entre otras consecuencias, a establecer una nítida distinción entre los seres humanos y los demás animales, a fundamentar nuestro juicio tanto de los animales como de nuestra propia animalidad. En el primero, se respondía no con referencia a deseos, percepciones y creencias, sino desde las propiedades de entidades fisiológicas (tendones, nervios, huesos). Los diferentes tipos de procesos cognoscitivos percepción, imaginación, pensamiento - son reducidos a términos fisiológicas idénticos, al interpretarlos como ciertos movimientos de átomos ${ }^{14}$. Aristóteles considera que no es así como el alma mueve al cuerpo, sino mediante alguna especie de elección y pensamiento ${ }^{15}$. Ve complementarias ambas explicaciones; y la interacción entre los procesos cognoscitivos y el deseo da como resultado la acción.

Hay que matizar con referencia a Platón. Mientras en los diálogos medios se encuentra una dicotomía; por una parte está el intelecto autosuficiente, que se mueve a sí mismo, puramente activo, generador de actos valiosos; y, por otra, los apetitos corporales, en sí mismos pasivos y nada selectivos; en el Fedro, en cambio, con su concepción del valor, presenta

12 Martha G. Nussbaum, La fragilidad del bien. Fortuna y ética en la tragedia y la filosofia griega, trad. A. Ballesteros, Visor, Madrid, 1995 (orig. 1986). Para este apartado me fueron especialmente útiles los capítulos «Los animales racionales y la explicación de la acción», pp. 343-372, y «La deliberación no científica», pp. 373-401.

13 Cf., bibliografía sobre las dos tradiciones y sobre los orígenes del estoicismo, A. López Eire, ob. cit., pp. 16-18, nn. 10-16.

14 Cf. frs. 549, 553, 554 (= fr. 9 , Sexto Empírico, adu. math. VII 135 y 136; fr. 11, Sexto Empírico, Adu. math. VII 138), en Vv. Aa., Los filósofos presocráticos, Madrid, 1987², pp. 570-571; 573

15 En lo referente al alma, si se mueve o no y, si se mueve, cómo se mueve, cf. el estudio que Aristóteles ofrece en De anima I 3-5; II 4; II 9; y principalmente, I 3, 406b24-25. 
una nueva visión de la acción; la causalidad del intelecto entraña receptividad y respuesta; y la causalidad del deseo es más activa, más selectiva; también en Las Leyes X se encuentra la explicación psicológica, donde "movimientos del alma" son numerosos elementos sin conexión con el intelecto, y éste no se considera separado de aquéllos.

Aristóteles, siguiendo esta última vía mencionada de Platón, elabora una explicación del movimiento y de la acción en el conjunto del reino animal. En su amplia investigación vincula el estudio del ser humano al del conjunto de los seres vivientes. "Parece buscar un ajuste entre el saber sobre la acción humana y nuestras opiniones acerca del movimiento de los seres vivos del universo" 16 .

Para Aristóteles el deseo (óp\& $\xi 1 \varsigma$ ) indica la característica común a todos los movimientos animales dirigidos a un objeto ${ }^{17}$. En todo movimiento, incluso en el acorde con el intelecto, interviene alguna clase de ó $\rho \varepsilon \xi$ ıs. En sus acciones racionales y no racionales, los seres humanos y el resto de los animales, para el estagirita, se esfuerzan por alcanzar objetos del mundo, y,

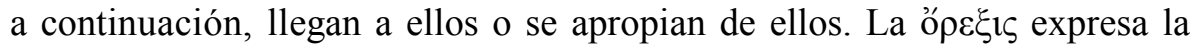
intencionalidad del movimiento animal con su orientación a un objeto y su respuesta no al mundo como tal, sino a la visión que se tiene de él, y desmitifica la acción racional, similar a otros movimientos animales ${ }^{18}$.

Son "motores del animal", para Aristóteles, los factores cognoscitivos y orécticos $^{19}$. Nuestras concepciones generales del desear, el percibir y el

16 En este aspecto son interesantes los tratados, Sobre el movimiento de los animales y Acerca del alma, siendo ésta última escrita anteriormente, ya que hay referencias en la primera, cf. De motu 6, 700b4-6. Cf., también, Nussbaum, op. cit., p. 344; y la «Introducción» de E. Lledó Iñigo, en Aristóteles. Ética Nicomáquea. Ética Eudemia, ob. cit. pp. 48-56.

17 Cf., Aristóteles, De anima III 9-11. La conciencia del placer y dolor es condición

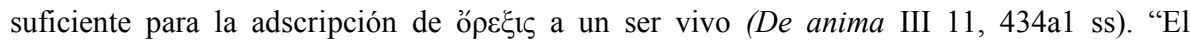

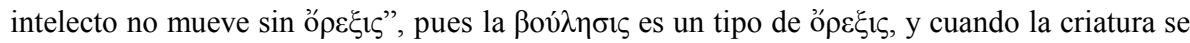

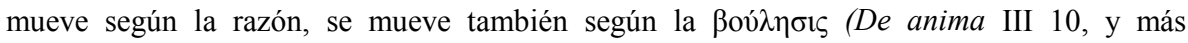

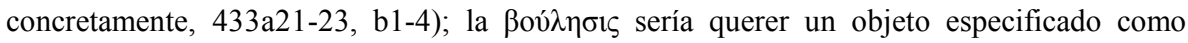
resultado de algún tipo de deliberación.

18 Cf., Nussbaum, ob. cit., pp. 356-357, y n. 35.

19 Cf. Aristóteles, De motu 6; enumera cinco elementos que denomina "motores del animal": el razonamiento, la imaginación ( $\varphi \alpha \nu \tau \alpha \sigma i ́ \alpha$, relacionado con el término $\varphi \alpha i ́ v \varepsilon \sigma \theta \alpha 1$,

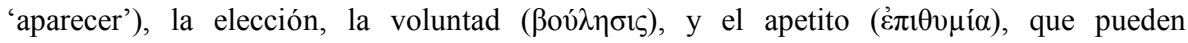

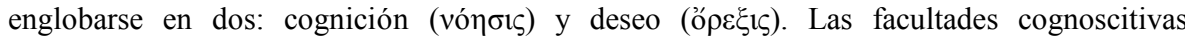
presentan al animal numerosos objetos del mundo; de ellos algunos serán objeto de cierto tipo 
movernos hacia un objeto están interrelacionadas lógicamente. Establece la

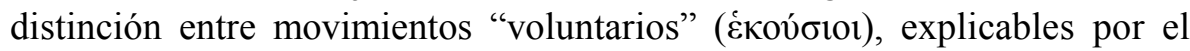
animal mismo y no por alguna fuerza externa que utilice a éste como

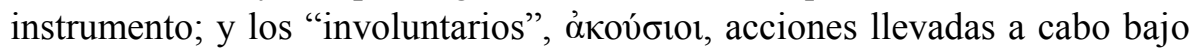
coerción física externa o por ignorancia excusable. Los "voluntarios" son

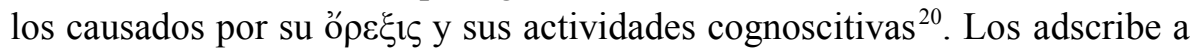
los adultos humanos, a los niños y a los demás animales: aunque estos últimos carecen de la facultad de deliberación, de elección y de los principios generales; tienen en común con los adultos que la causa de sus acciones no es la necesidad física, sino su propia visión del mundo y su óp $\varepsilon \xi 1 \zeta$.

Expresado con una gran simplificación, parece que a partir de Aristóteles - siguiendo luego Hume y Kant -, se establece el modelo clásico que representa la racionalidad humana como una versión más inteligente de la racionalidad del simio ${ }^{21}$.

Searle formula, en una crítica moderna, una concepción más compleja de la racionalidad en los siguientes términos: «No hay una facultad separada de la racionalidad distinta de capacidades tales como aquellas que tienen que ver con el lenguaje, el pensamiento, la percepción y las distintas formas de intencionalidad, puesto que las constricciones racionales están incorporadas en, o son internas a, la estructura de la intencionalidad en general, y del lenguaje en particular» ${ }^{22}$.

de órexis y otros no. Y entre los primeros, una parte estará disponible o será posible. Lo "bueno" y lo "posible" deben darse juntos para que se produzca el movimiento. Así, parece que el elemento oréctico y el cognoscitivo son cada uno causas del movimiento necesarias y (en ausencia de impedimentos) conjuntamente suficientes. Cf. De motu 6, $700 \mathrm{~b} 11$ - 701b1; y Nussbaum, ob. cit., p. 358.

20 Cf., Arist., De motu, 11, 703 b 2 - 704b2.

21 Cf., J. R. Searle, Razones para actuar. Una teoría del libre albedrio, Gijón, 2000; con un glosario del traductor, Luis M. Valdés Villanueva, quien ha vertido al castellano otras obras del mismo autor, que citaremos. Searle va un paso más allá: «En la racionalidad humana, en tanto que opuesta a la racionalidad del simio, hay una distinción entre las razones para la acción, que es algo que tiene que ver enteramente con la satisfacción de algún deseo, y razones que son independientes de los deseos». pp. 18-19.

22 Tal vez, quede más claro en la siguiente formulación suya: «si uno tiene un animal que tiene la capacidad de formarse creencias sobre la base de las percepciones, tiene la capacidad de tener creencias y deseos, y tiene también la capacidad de expresar todo esto en un lenguaje, entonces uno tiene ya las constricciones de la racionalidad incorporadas en su 
Si seguimos a Searle, para mejor hacernos comprender el concepto de la racionalidad, este autor necesita introducir el concepto de "brecha" (gap en inglés); para él el conjunto de creencias y deseos de un agente, previas a la realización de la acción, no es causalmente suficiente para determinar la acción; es lo que él llama el fenómeno de la "brecha"; y éste debe darse para poder hablar de toma racional de decisiones. Sólo tenemos racionalidad allí donde se tiene la posibilidad de irracionalidad, y este requisito entraña la posibilidad de elegir entre lo racional y lo irracional ${ }^{23}$. Según Searle, contrariamente al modelo clásico «hay razones para la acción independientes del deseo» ${ }^{24}$. Y «las razones inconsistentes para la acción son comunes $\mathrm{y}$, de hecho, inevitables. No hay ningún requisito racional al efecto de que la toma racional de decisiones tenga que comenzar con un conjunto consistente de deseos, $\mathrm{u}$ otras razones primarias, para actuar» ${ }^{25}$.

Nos interesa volver a la doctrina de Aristóteles - que como vemos sigue siendo punto de partida y de debate en la actualidad -, ya que es la que nos lleva a una mejor comprensión del texto de Eliano. Una acción es responsable, para el estagirita, sólo si es la acción voluntaria de una criatura

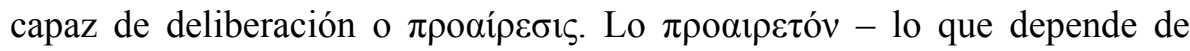

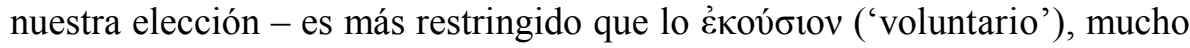
más amplio, pero no hay oposición entre ambos. La causa de lo "voluntario" - que no se contrapone a la de la acción deliberada - es la explicación de la base animal de algunas actitudes y prácticas éticas esenciales en el desarrollo de una criatura animal hacia la acción deliberada. Es decir, es la base necesaria para un desarrollo futuro más complejo. Ambas distinciones son como explicaciones de dos conceptos relacionados que desempeñan funciones complementarias en la teoría ética aristotélica. La concepción aristotélica del desarrollo y la formación moral ayuda a comprender algunos de los motivos que justifican la conservación de las dos distinciones. Basta hacer notar que el niño, en su desarrollo, se convierte en un adulto capaz de proáiresis, o sea, de deliberar sobre los valores, de criticar, de modificar sus deseos. Este proceso habría que ponerlo en relación con el interés profundo de Aristóteles por la educación y su afirmación de que la función más importante de la política es formar a los jóvenes para que puedan vivir bien

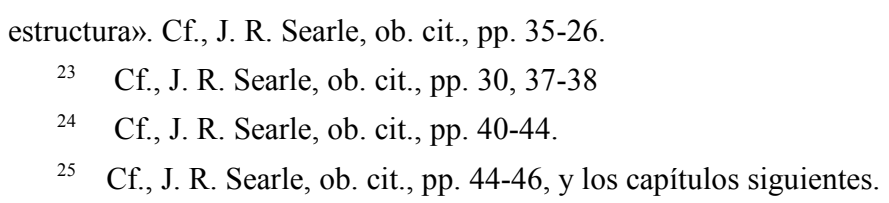


según sus propias decisiones. De ahí que a partir de las dos explicaciones, la

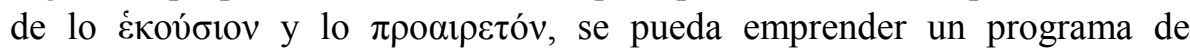
educación y formación de hábitos que no se reduce a la manipulación del comportamiento $^{26}$. Simplificando mucho, según la doctrina de Platón, se podría decir que existe solamente una alternativa: de una parte, la necesidad propia de las bestias, y, de otra, la causalidad puramente activa de la razón. Pero la existencia y la eficacia de determinadas prácticas éticas demuestran que los apetitos no son tan simples y exclusivos de las bestias como afirma Platón, meros impulsos efecto de otros, como los movimientos del sistema digestivo. Se aconseja y forma a las personas tanto en sus tendencias apetitivas como en las puramente intelectuales. Se educa al niño para que se desarrollen en él deseos gratificantes apropiados, no suprimiendo sus impulsos, sino modificando sus decisiones mediante el discurso y la interacción motivacional. Por tanto, las fuerzas apetitivas han de tener una medida de racionalidad, algo parecido al hacer caso de los consejos paternos $^{27}$. La selectividad intencional del apetito muestra que éste se puede comprometer en la búsqueda del bien. Si no menospreciamos lo animal ni sobrevaloramos lo racional, estaremos en condiciones de comprender hasta qué punto lo uno contribuye al florecimiento de lo otro ${ }^{28}$.

Lo más interesante para el tema que nos ocupa, del que no querríamos apartarnos, es que ya desde antiguo, según se observa en esta doctrina aristotélica, se ofrece una atrayente explicación de la base animal natural desde la que se desarrolla el carácter moral. Y además éste es el marco general al que queríamos llegar, para comprender básicamente, con una

26 Se encuentran numerosos pasajes en que Aristóteles distingue a los adultos humanos de los niños y los animales, cf. Nussbaum ob. cit., p. 367, n. 62. La alabanza y la censura podrían ser condicionamientos exteriores y, a la vez, maneras apropiadas de comunicarse con un ser inteligente que actúa según su propia visión del bien. Y si se piensa en lo que sucede, cuando se educa a un niño, la insistencia de Aristóteles en la función crucial de la intencionalidad y la atención selectiva parece mucho más correcta empíricamente que el conductismo de otros autores que puede derivar de la doctrina platónica.

27 Cf., Arist., EN I 13, 1102b29-36; cfr. EE II 1, 1219 b27 ss. Cf. Nussbaum, ob. cit., p. 369.

28 Si volvemos la vista a nuestro mundo moderno, J. R. Searle trata de ofrecer una teoría general de la intencionalidad como fenómeno biológico primitivo, que debe explicarse en términos de la estructura física y biológica del cerebro; cf. su obra, Intencionalidad. Un ensayo de filosofia de la mente, trad. esp., Madrid, 1992 (1983); la intencionalidad individual se ve completada por el autor con una explicación de la intencionalidad colectiva en $L a$ construcción de la relidad social, trad. esp., Barcelona, 1998 (1995). 
fundamentación ideológica precedente, el objetivo moralizante, casi único, por medio del mundo animal, en la obra de Eliano.

No obstante, el pensamiento de Aristóteles va más allá con referencia al ser humano. Cuando la areté era una forma de pensar el placer y el dolor en el espacio de una naturaleza que se modifica y enriquece por la paideia, el nacer en la polis, en una convivencia social, es algo más que nacer en la matriz de la naturaleza ( $\varphi v ́ \sigma i \varsigma)$. El animal que habla, reacciona ante estímulos más complejos. Viene bien la cita de Aristóteles en que refiere cómo el ser humano, como animal que habla, se eleva de esa fuente originaria $^{29}$. En el mundo de la cultura, en el mundo creado por el hombre, para Aristóteles, el placer y el dolor no expresan únicamente las reacciones del cuerpo y los sentidos. De lo contrario no podríamos salir de la misma naturaleza. Aunque esas dos "fuentes de la vida" sean imprescindibles para

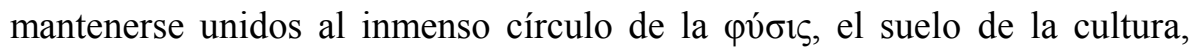
exclusiva creación humana, se ha extendido por espacio mucho más amplio $^{30}$.

En cambio, si se viven momentos, no de plenitud, sino de lo contrario, de decadencia y debilidad, a partir de la matriz concreta de la historia, o bien de la evolución de la teoría que sustenta el pensamiento individual, surge esa involución ideológica, que, en términos generales, queremos vislumbrar en el pensamiento profundo de Eliano. Precisamente, en tales circunstancias, se quiere volver a este núcleo originario, cuando la cultura, la política, en una palabra la ideología, han enturbiado los contenidos de la areté.

Y termino este excursus, conveniente para nuestra investigación, con las citas de Tucídides y de Aristóteles, de manera válida utilizadas por Nussbaum en su doctrina aristotélica. Dice Tucídides por boca de Pericles:

Debéis comprender el poder real de Atenas contemplándolo de hecho día tras día y

29 Arist., Pol. I 2, 1253a10-18: "La voz es signo del dolor y del placer, y por eso la poseen también los demás animales, porque su naturaleza llega hasta tener sensación de dolor y de placer y significársela unos a otros. Pero la palabra es para manifestar lo conveniente y lo perjudicial, así como lo justo y lo injusto; y esto es propio del hombre frente a los demás animales: tener él solo el sentido del bien y del mal, de lo justo y de lo injusto, y de los demás valores. La participación comunitaria de estas cosas es lo que constituye la casa y la ciudad". Estas ideas, también en Pol. III 9, 1280b5; EN IX 9, 1167b2; Pl. R. VI 484d.

30 Sigo muy de cerca el capítulo de E. Lledó, «Aristóteles y la ética de la pólis», en Historia de la Ética, ob. cit., pp. 137-207; cf., asimismo, del mismo autor, la interesante Introducción a Aristóteles. Ética Nicomáquea. Ética Eudemia, ob. cit., pp. 7-119. 
convirtiéndoos en sus enamorados. Y cuando os impregne su grandeza, habéis de reflexionar en que ganaron todo esto hombres que mostraban su valor y conocimiento de su deber y que tenían un sentido de la dignidad de la conducta (..), y vosotros imitándolos y juzgando que la felicidad (la vida humana buena) se basa en la libertad, y que la libertad en el valor, no miréis demasiado los peligros de la guerra ${ }^{31}$.

Y Aristóteles dice:

Porque así se mueven y actúan los animales: la causa inmediata del movimiento es el deseo, y éste aparece, bien mediante la percepción, bien por la imaginación y el pensamiento. $\mathrm{Y}$ respecto a las criaturas que desean actuar, es a veces por el apetito o la emoción y otras por el deseo racional como crean o actúan ${ }^{32}$.

Ambos textos tienen en común una explicación similar de la acción animal que no separa al ser humano de la Naturaleza. La cita tucidídea hace pensar que su autor está resuelto a rebajar las pretensiones del intelecto; o, más bien, de cualquier interpretación de la acción y la racionalidad humanas que separe al ser humano del mundo de la naturaleza al que pertenece. Pericles, en sus palabras, parece deseoso de destacar la riqueza y complejidad del comportamiento animal en el mundo de la naturaleza. La acción y el ser humano son colocados de lleno en el seno de la Naturaleza: el ser humano es una criatura de amor y deseo, incluso en sus acciones racionales. Pero el deseo, y esto es aplicable de manera cierta a los animales, no es un impulso meramente bestial; supone, según Aristóteles, una atención selectiva a los objetos del mundo y un conjunto de reacciones o respuestas a dicha atención asimismo selectivas. La falta de autosuficiencia es característica de toda vida animal, incluida la nuestra.

Este panorama descrito nos ha llevado a la común naturaleza animal base del desarrollo moral y a la gradual diferencia en esa escala natural, dentro de los seres que se mueven y sienten dolor y placer -animales, niños, humanos adultos-, y nos ha introducido en una reflexión más profunda sobre la consideración moral de los animales; la doctrina aristotélica, creemos, ha brindado al estoicismo y al pensamiento de Eliano un fundamento para la valoración ética.

¿En qué circunstancias históricas Eliano acude al reino animal, no humano, para mejorar moralmente a los seres humanos?

La pregunta nos lleva a plantear, en primer lugar, aunque sea de manera sintética, tanto los factores socio-económicos, como los ideológicos, en

31 Thuc. II 43

32 Arist., De motu 701a33-701b1. 
conexión con el mundo de la política y de la ética social de la época en que vive Eliano; todo ello contribuirá a explicar el pensamiento que rezuma la obra de este autor.

\section{La Estoa y Eliano en el mundo del Imperio Romano.}

Como sofista, hombre intelectual y curioso moralista de su tiempo - ca. 170-235 d.C. -, ese material que recoge lo elabora, informa y transforma, de manera peculiar, con el enfoque preferido por el autor. El cargo que ejerce

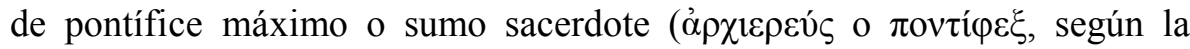
Suda), cargo elegible y vitalicio, que requiere un modo de ser y exige unas determinadas condiciones, podría indicar algo de su talante conservador y de cómo aplica, de manera convencida, la filosofía a la religión y la ciencia a la moral. Eliano solía decir, según Filóstrato, que no se había ausentado de Italia en toda su vida, y por ello "se le apreciaba aún más en Roma, como a persona que tiene en mucho los usos tradicionales" 33 . Por otro lado, aunque desempeña el cargo muy probablemente en Preneste, próxima a Roma, pasa su vida en Roma y frecuenta el círculo de la inteligente y culta emperatriz Julia Domna, esposa del emperador Septimio Severo, entre cuyos miembros se encontraban los intelectuales más destacados de Roma (Opiano, Filóstrato, Galeno, Diógenes Laercio, y otros). Estos datos personales nos hacen suponer que es un buen conocedor de las costumbres de la sociedad en que vive y de las conductas de la casa imperial, en aquella época declinante del Imperio Romano. Muy probablemente alude a su satisfacción personal de sentirse entre los intelectuales de aquellos tiempos, al decir en el Epílogo que si otros buscan riquezas, poder y honores, a él le consume otro deseo bien diferente: el de conocer a los animales, reunir todo el material sobre ellos y observarlo ${ }^{34}$. Y de modo más abierto llega a confesar su aspiración máxima de pertenecer al gremio de los intelectuales ${ }^{35}$; pudiendo

33 Cf., Philostr., VS II 31, 625.

34 Ael., NA, Epilog. Para el texto de Claudio Eliano sigo las ediciones y versiones siguientes: Aelian. On the characteristics of animals, 3 vols., por A. F. Scholfield, The Loeb Classical Library, London, 1958; F. Maspero, Claudio Eliano. La natura degli animali, Biblioteca Universal Rizzoli, Milán, 1998; ambas bilingües, dependen de la de R. Hercher (Bibl. Teubner, 1864); J. Ma Díaz-Regañón López, Claudio Eliano. Historia de los animales, I-II, Gredos, Madrid, 1984; J. Vara Donado, Claudio Eliano. Historia de los animales, Akal, Madrid, 1989.

35 Ael., NA, Epilog.: "No me gusta que me cuenten entre los hombres ricos ni que se me 
andar pavoneándose de manera arrogante, dice, y hacerse notar en las cortes de los príncipes y llegar a alcanzar gran riqueza, elige dedicar su tiempo libre a su obra, desoyendo las críticas de los que sólo buscan honores, poder, riquezas y todo lo que sea ocasión de gloria ${ }^{36}$.

Si no fue un estoico, es sin duda de aquellos convencidos que difunden sus creencias. Su simpatía con la ideología estoica se puede deducir por los

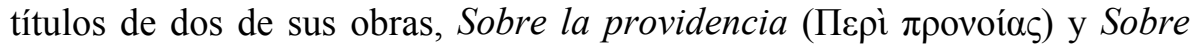

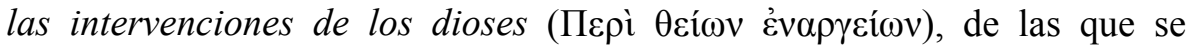
conservan algunos fragmentos; son escritos filosófico-religiosos inspirados en la doctrina estoica; contenían relatos con el fin de inculcar la idea de que los incrédulos reciben el castigo por su incredulidad; tesis que mantiene con frecuencia en su obra sobre los animales ${ }^{37}$. En ellos se condena el escepticismo de los epicúreos, cuyo jefe según Eliano, experimenta en su propia carne las iras de los dioses negados por él ${ }^{38}$. Me recuerda la obra del también sacerdote, en este caso del santuario de Delfos, Plutarco, cuyo título ya expresa la esencia de su contenido teológico, Sobre el retraso de la venganza divina (De sera numinis uindicta), escrita entre el los años 90 a 100 d.C., en la que el pensamiento estoico ejerció también una fuerte influencia. Es probable que Eliano conociese la obra de Plutarco, quien no era un desconocido para los Padres de la Iglesia de los siglos siguientes y mucho menos para la literatura pagana de siglos sucesivos ${ }^{39}$. El queronense,

compare con ellos. Pero sí intento yo por todos los medios y quiero pertenecer el grupo de aquellos doctos poetas y hombres expertos que consideraron digno conocer y, a la vez, examinar los secretos de la Naturaleza, y tratadistas que han llevado su experimentación a lo más alto. Es evidente que soy yo mejor consejero de mí mismo, que la decisión de aquellas personas. Pues yo prefería sobresalir en un conocimiento culto, incluso de una sola disciplina, que por las cacareadas riquezas y posesiones de los muy ricos".

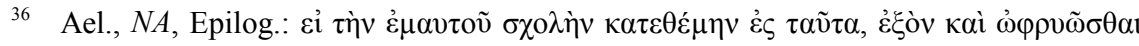

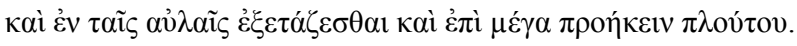

37 Cf., Ael., NA XI,19; XII, 32: la Naturaleza, según Eliano, incluso a los irracionales en este caso se trata de un tipo de serpientes de la India - les inflige castigo; y se aducen estos hechos, dice Eliano, para instrucción de personas inteligentes.

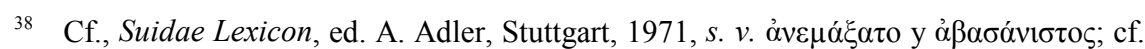
asimismo, M. Wellmann, «Claudius Aelianus» (Aỉı $a v o ́ \varsigma)$, Pauly-Wissowa, RE, I, Stuttgart, 1893, cols. 486-488.

39 Como lo muestra Proclo al citar varios pasajes de la obra (en De decem dubitationibus circa providentiam, en la VIII y IX dubitatio); cf., K. Ziegler, Plutarco, 1965, en «Gli scritti teologici», p 254. 
por su actividad política $\mathrm{y}$, sobre todo, por el ejercicio del cargo de sacerdote en el santuario de Apolo en Delfos, mantuvo amistosas relaciones con los grandes de Roma, así con Sosio Seneción, amigo y confidente de Trajano, quien contribuye de manera relevante para la mejora de la propiedad del santuario y a erigir construcciones nuevas en ese tiempo ${ }^{40}$. El estoicismo era la ideología más extendida y que más había calado en la sociedad greco-romana de la época imperial.

Entremos, con no mucho detalle, en esta doctrina, la más imperante en la época de Eliano que junto con su vocación de erudito y científico al modo de su tiempo (con aspecto de anticuario-científico), le han estimulado y empujado a esta investigación sobre los animales y a elaborarla y darle una orientación filosófico-religiosa, impregnada de moral, fruto de su eclecticismo ideológico: doctrina platónico-aristotélica restaurada, doctrina propia de los estoicos fundadores en contacto con el pensamiento de los cínicos, pensemos en Antístenes, y la de los epígonos greco-romanos, y creencias y tradición religiosa romana, llenas de superstición y conservadurismo. Confusión del campo de la conciencia individual y de los deberes sociales, estudio de la Naturaleza con fines religioso-filosóficos y didáctico-morales.

Los estoicos proclaman que vivimos un kósmos ("un universo ordenado"), cuyos planes se identifican con un Lógos (Razón) inmanente y divino, cuya Providencia cuida, a través de la cadena indefectible de las causas y de los efectos, el conducirlo por un rumbo predeterminado con infinita sabiduría. El conocimiento de la Naturaleza es el conocimiento de Dios, es la Razón universal que anima el cosmos; y el actuar del hombre debe quedar integrado en el curso del acontecer universal, en ese sentido proclaman que conviene que sea acorde con la Naturaleza. El ser humano que racionalmente se atiene en su conducta a ese ideal de vivir de acuerdo con la Naturaleza y acepta sin oponerse el sucederse normal de los acontecimientos, es decir, esa proyección del Lógos divino universal sobre el orden de los sucesos llamada Hado, consigue el ideal más alto del sabio ${ }^{41}$.

Los seres racionales deben considerar valioso solamente lo razonable, lo

40 Cf., Plu., De pyth. orac. 29, 409.

${ }^{41}$ Cf., entre otros, sobre el estoicismo en el marco de la filosofía helenística, con bibliografía adecuada, C. García Gual, M J J. Imaz, La filosofía helenística: Éticas y Sistemas, op. cit., pp. 112-171. J. C. García Borrón, «Los estoicos», en Historia de la ética, ob. cit., pp. 208-247; y la Introducción de A. López Eire a su edición bilingüe, ob. cit., pp. 11-67. 
que el lógos nos indica como nuestra relación con la naturaleza y con los demás hombres y las determinaciones y deberes que se siguen de tal conocimiento. El atenerse así a lo razonable es la virtud, y en ésta se basa la

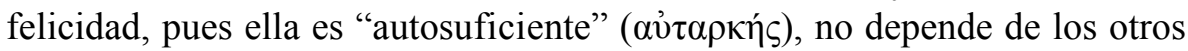

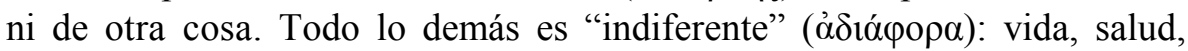
honor, riqueza, placer, no son, en sí y por sí, bienes, como no son en sí y por sí males la muerte, la enfermedad, la pobreza, las afrentas, el dolor. Para el virtuoso la felicidad verdadera está en el sentirse libre de toda perturbación exterior, en la independencia y la tranquilidad interna. También los epicúreos predican la independencia y la calma interior, pero buscaban la "ataraxia" en la reclusión del sabio, lejos de la multitud y de la actividad pública. Los estoicos afirman la solidaridad y la vida activa y proclaman el parenteso natural de todos los hombres.

Naturalmente los distintos estoicos disintieron en la valoración de los

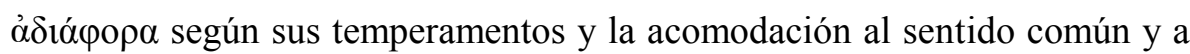
las circunstancias históricas en las que viven ${ }^{42}$. El sabio radicalmente ajustado a la pura doctrina se convirtió en un ideal regulativo más que en una exigencia de realización práctica. El sabio real podía tener vida privada, amar, casarse, procrear, ser rico, participar en la vida pública, sobre todo en Estados dirigidos por un ideal de progreso moral.

La tesis estoica de que los individuos están subordinados al conjunto y de que los males cotidianos quedan justificados en el orden de la totalidad, sirvió como elemento ideológico a la política totalitaria del Imperio Romano. La visión estoica del mundo, por su propia naturaleza y por la orientación final que imprime a la conducta humana, conduce a la aceptación de la realidad en todos sus niveles, incluido el orden social y político $^{43}$. Su ideario pudo servir como una ideología conservadora,

42 Zenón creyó que debía distinguirse entre lo contrario a la naturaleza, realmente "indiferente" o "no-valioso" ( $\alpha \dot{\pi} \alpha \dot{\xi} \xi$ iov), para el sabio, y algunas cosas que, indiferentes en el sentido de irrelevantes para la moralidad, pueden ser sin embargo "privilegiadas" o "preferibles" ( $\pi \rho \circ \eta \mu \varepsilon \dot{v} \alpha)$, como la salud y el vigor físico, inncluso la riqueza, que no son contrarias a la naturaleza y mejoran nuestra vida.

43 Se puede decir, siguiendo a Puente Ojea, que «la ética estoica postula una vocación humanizadora y de espiritualización de las relaciones comunitarias, y un ideal de justicia,

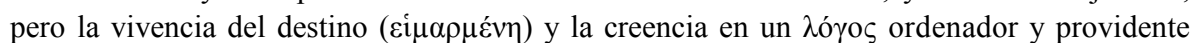
( $\pi \rho$ óvol $\alpha$ ) imponen, a la postre, una voluntad incesantemente renovada de conformidad con las eventualidades cotidianas en cuanto signos de la arcana dispensación natural. Siempre debe estar mirando al todo y eso le basta»; cf., su Ideología e Historia. El fenómeno estoico 
colaborando a una defensa teórica del orden político establecido, por lo maleable y capaz de transformación adaptándose a los tiempos, en su sucesiva inserción socio-política ${ }^{44}$.

La idiosincrasia del pueblo romano, en la época republicana, conlleva rasgos que habían de aproximarlo a la ética estoica. El romano propendía, por carácter y por la peculiaridad de su organización social y económica a primar la actividad práctica y los deberes. Solamente se precisaba acomodar el cuerpo de la teoría a los intereses reales de la praxis. Panecio de Rodas (ca. 185-109 a. C.) es el gran arquitecto de la nueva formación ideológica, que confería un estatuto teórico adecuado a los intereses de las clases altas de la sociedad romana, junto con Posidonio de Apamea un poco posterior $(135-50 \text { a. C. })^{45}$. En ambos, se encuentra un desplazamiento similar de la perspectiva antropológica, propia del dogmatismo estoico originario. La vida psíquica del hombre presenta facultades que corresponden a los instintos de la vida animal, alejándose del dogma de un "principio rector"

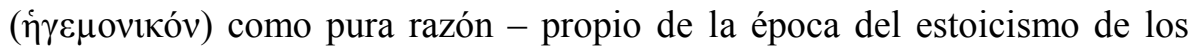
fundadores - , y condenando el intelectualismo riguroso, en aras de una

en la sociedad antigua, ed. Siglo XXI, Madrid, 1974; véase, entre otras, las pp 33-37. Y de Giorgio Agamben, Homo sacer. El poder soberano y la nuda vida, ed. Pre-Textos, Valencia, 1998, pp. 45-67.

${ }^{44}$ Como bien ha señalado Puente Ojea, el estoicismo post-alejandrino o helenístico (ss. IV-III a. C.) y el estoicismo de la época imperial (ss. I-III d. C.) corresponden, respectivamente, a períodos políticos en los que la anarquía o el agotamiento se reflejan ideológicamente en actitudes de evasión o de resignación. Por el contrario, el estoicismo helenístico-romano (s. II-I a. C.) refleja el momento en que aparece una potencia con grandes energías, en el mediterráneo oriental. En ese momento histórico, el estoicismo, mediante la asimilación de elementos eclécticos y oportunas acomodaciones, desempeña una función ideológica nueva al servicio del ethos latino y de los intereses hegemónicos de la República romana, y adopta una actitud de abierta colaboración; cf., ob. cit., pp. 32-33.

45 Cf., Puente Ojea, ob. cit., pp. 139-150, sobre Panecio y Posidonio. Expone las bases teóricas del estoicismo para la época del apogeo romano, pp. 133-164; y en pp. 165-239 desarrolla la ideología estoica para el declive del mundo antiguo, en la época del Imperio Romano; sobre la importancia de los epígonos del estoicismo romano, principalmente, Musonio Rufo, Séneca, Epicteto y Marco Aurelio, pp. 199-213. Véase también, «El estoicismo mitigado y romanizado de Panecio», «La renovación del sistema en Posidonio» y «De Musonio a Marco Aurelio», por J. C. García Borrón, en Vv. Aa., Historia de la Ética, ob. cit., pp. 224-247. Sobre diferentes aspectos (económico, político, religioso, social) de la decadencia y crisis del Imperio romano, cf. R. Rémondon, La crisis del Imperio romano. De Marco Aurelio a Anastasio, $1979^{3}$, pp. 3-42; 155-181; S. Mazzarino, El fin del mundo antiguo, México, 1961, pp. 28-34. 
concepción integral y pragmática de la vida moral. Posidonio señala que en

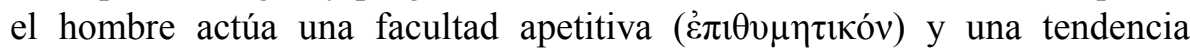
instintiva $(\theta v \mu o ́ s)$; aunque ambos exponentes de la vida instintiva se subordinan a la razón ( $\lambda$ ó $\gamma$ $\varsigma$ ), jamás cesan de su propia naturaleza autónoma. Conciben ahora los afectos como factores fundamentales de la

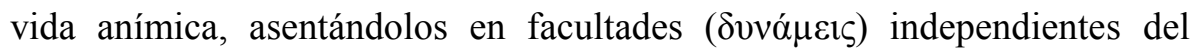
$\lambda$ ó $\varsigma_{\zeta}$ y relevantes en la actividad del "principio rector" ${ }^{46}$. Volvemos a la doctrina aristotélica con referencia a la base animal de la acción moral. Pero ahora con un marcado sentido espiritualista. El panteísmo organicista y vitalista de Posidonio, centrado en un espíritu divino instalado en el cielo (oủ $\alpha v o ́ s$ ) y verdadero guía cósmico, había de transformarse en la referencia tácita o expresa de las concepciones del estoicismo en la época imperial ${ }^{47}$.

Trasladándonos a estos tiempos históricos del Imperio Romano, para este nuevo clima social se necesitaba reafirmar teóricamente el ideal del sabio de la tradición estoica, aunque con un talante bien distinto del de Zenón o

46 La consecuencia es importante: la raíz de la infelicidad personal no estaba situada, toda ella, en la corruptora influencia de la convivencia social y de la comunidad política como pregonaban los primeros estoicos, impregnados aún de cinismo -, sino en la propia estructura psíquica del hombre. Por tanto la vida social y el quehacer público no sólo no constituían un riesgo para la eudaimonía, la felicidad, sino que, por el contrario, era el mejor camino hacia la disciplina de los instintos que laten en el seno de la naturaleza humana. Para Panecio y Posidonio, el alma impregna la totalidad del cuerpo, en incesante interacción recíproca. Separa, sin embargo, a ambos pensadores el destino del alma; Panecio rechaza toda presunción de inmortalidad. Para Posidomio, con una visión aún platonizante del credo estoico, el alma pura, $\pi v \varepsilon \tilde{u} \mu \alpha$ individual es el $\delta \alpha i ́ \mu \omega v$ personal - espiritu divino particularizado en cada hombre -, que liberada del cuerpo, se remonta a los altos espacios siderales para gozar allí de una existencia plena; el filósofo de Apamea, aunque integrado en la clase directora de la República rodia, asume la preocupación honda del destino del alma después de la muerte, para integrarla en el misticismo astral, originario de Mesopotamia y reelaborado en la Hélade. Esa religiosidad de orientación mística se iría extendiendo en los siglos siguientes a la totalidad del Imperio, siendo el substrato de la propaganda cristiana; cf., Puente Ojea, ob. cit., pp. 144-147.

47 El ser humano, imagen del ser divino, no será sólo parte ( $\mu \varepsilon ́ \rho \varsigma)$ del mundo, como las demás cosas, sino miembro ( $\mu \varepsilon \dot{\lambda} \mathrm{\varsigma} \varsigma)$ del gran organismo. El individuo que es un miembro se debe al organismo universal. La teoría psicológica desemboca, dice Puente Ojea, en una ética de muy nuevas resonancias y muy en función de la sociedad romana de esa época. Se trata de integrar la conciencia en la circunstancia vital, de insertar la vida moral del hombre en la trama de sus determinaciones externas. El espíritu humano crea la civilización como una segunda naturaleza, en el marco del designio finalista del $\lambda$ ó $\gamma$ o $\varsigma$ cósmico. Al apogeo de Roma en la época republicana, el estoicismo le aporta la ideología adecuada a su optimismo político y económico-social. 
Crisipo, si bien las obras de estos filósofos recuperaron su gran prestigio en el magisterio de la escuela. Hay una vuelta al purismo de los fundadores, pero en el seno de una praxis moral muy diferente. La influencia de Panecio y Posidonio es manifiesta en todo momento. La moral práctica de esta época se define por un estrechamiento de los vínculos entre filosofía y sentimiento religioso; alejamiento del Estado y de la vida pública, concentrándose el hombre en la salud de su alma individual; repliegue del individuo sobre sí mismo, remodelando su fe estoica según sus exigencias personales, en base a su ciencia y a su conciencia ${ }^{48}$. Marco Aurelio reitera de manera continua esa interiorización del ideal de salvación del alma, en el contexto de una sociedad que impone deberes políticos ineludibles. De ahí la necesidad de la educación, para aprender a adaptar de modo acorde con la naturaleza el concepto de lo razonable y lo irracional a los casos particulares.

Existe una vivencia en los estoicos de esta época que les hace considerar a Roma a la vez como garantía de la seguridad y como causa del desorden moral $^{49}$. En pleno apogeo del Imperio se dan los síntomas de su ruina. Los estoicos en esta época estaban radicalmente insertos en la civilización romana como en una segunda naturaleza, pero las calamidades sociales no podían dañar la conciencia, cuyo origen divino garantiza la superioridad y autonomía del yo individual.

Este marco ideológico podría ser el que más ayuda a comprender ese pesimismo y amarga resignación del autor de De natura animalium, el cual, con una verdadera convicción, dedica, a modo de vocación personal, gran parte de su tiempo a esa investigación sobre el mundo animal como fuente segura de moralidad, más bien de una ética conformista y resignada, pero muy útil para el hombre interior, para la conciencia de los seres humanos.

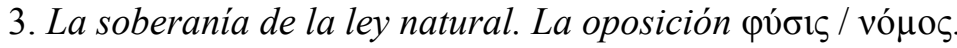

Me parece conveniente, en relación con Eliano, recordar las diferentes pespectivas en que se contemplaron los dos conceptos que subyacen en los

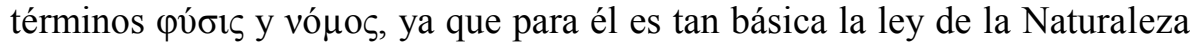
( $(v ́ \sigma ı \varsigma)$. Comencemos fijándonos en el estoico Cleantes (ca. 330-231 a. C.), en su Himno a Zeus, una de las cimas de la súplica antigua, en el modo de

48 Cf., Puente Ojea, ob. cit., p. 198. Para el pensamiento estoico de la época Imperial en Séneca, Epicteto y Marco Aurelio, pp. 199-213.

49 Cf., Puente Ojea, ob. cit., p. 222. 
dirigirse a ese dios de los mil nombres ${ }^{50}$, cómo celebra y canta su poder,

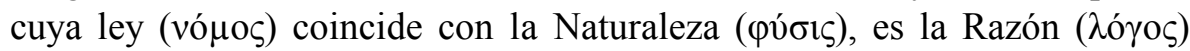

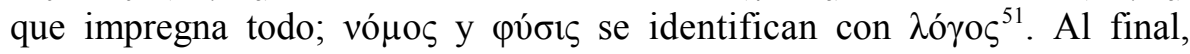
implora al dios para que proteja a los seres humanos de la luctuosa inexperiencia y disperse ésta de sus almas y conceda alcanzar el entendimiento ( $\gamma v \omega ́ \mu \eta \varsigma)$ en el que Zeus confiando, todo dirige con justicia, y puedan celebrar siempre con himnos y justicia la ley universal (Kovvòv vónov) (vv. 33-39). Canta la gloria y poder de Zeus, a quien invocan con derecho todos los mortales porque dice el estoico "de ti hemos nacido, provistos de una imitación del sonido, los únicos de cuantos animales mortales viven y se mueven sobre la tierra" (vv. 4-5).

Es digno de notar ese doble aspecto considerado por Cleantes que se encuentra también en el Prólogo de la obra de Eliano, expresado de diferente forma. Para este último autor, Dios dotó a los seres humanos de su atributo mas propio (la palabra), pero, a la vez, admira e investiga las cualidades impresas en los animales por la misma Razón universal. La ley de la Naturaleza (vó $\mu$ o $\varphi v ́ \sigma \varepsilon \omega \varsigma$ ), o Dios, es para Cleantes y para Eliano, ley inmutable, $\mathrm{y}$, en los dos autores, se identifican ambos conceptos, pv́бıৎ y vó $\mu \mathrm{o}^{52}$.

50 En los estoicos y, por tanto, también en Cleantes, es propia la polionimia de la divinidad; se identifica Logos, Naturaleza, Dios, Zeus. Cf. Diog. Laerc., VII 135, sobre la polionimia de Dios: "Una sola cosa son Dios, la inteligencia, el destino y Zeus, y con otros muchos nombres se la llama". Y en VII 147: "Dios es un ser vivo inmortal, racional, perfecto o inteligente en estado de bienaventuranza, incapaz de admitir nada malo, rector providente del mundo y de las cosas que en él se asientan; no tiene, sin embargo, forma humana. Es el artífice del universo y como padre de todas las cosas, tanto en general como en la parte de él que todo lo penetra y que es designada con muchos denominaciones según sus poderes", cf., A. López Eire, ob. cit., pp. 218-219.

51 "Zeus, fundamento de la Naturaleza, tú que con ley (vó 2-3). "Es a tí (Zeus) a quien todo el universo, girando alrededor de la tierra, obedece por donde tú lo conduzcas, y de buen grado se somete a tu imperio" (vv 7-8). Y sigue: "tal es el instrumento que tienes en tus manos invencibles, provisto de dos filos, inflamado, el siempre vivo rayo, bajo cuyos golpes, todas las obras de Naturaleza $<$ fin alcanzan; $>$ con él enderezas

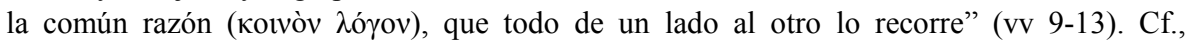

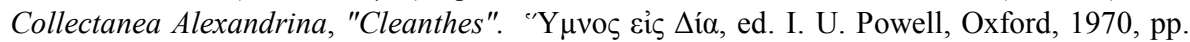
127-128. E. Des Places, La religion grecque, París, 1969, «Cléanthe. L'Hymne a Zeus», pp. 262-267.

52 Cf., Ael., $N A$ 4, 54; 9 1; este último pasaje se refiere al león, que una vez que es viejo y sin fuerzas, los cachorros lo agasajan con el botín que consiguen de su caza y en una buena 
Ese canto a la soberanía de la Ley natural, en los dos identificada con Dios, se remonta, lo sabemos, al Lógos de Heráclito que todo lo gobierna y que es "común", Lógos al que hay que escuchar, dice, para enterarse de que "todo es uno", es Dios, o lo que es lo mismo la Naturaleza ${ }^{53}$.

Y recuerda muy de cerca el fragmento de Solón en que pone en conexión violencia $(\beta i ́ n v)$ y justicia $(\delta i ́ \kappa \eta v)^{54}$. Solón, en el s. VI a. C., se está refiriendo a su actividad como legislador, en la que, sin ninguna ambigüedad, intenta reunir y hacer compatibles violencia ( $\beta$ ín) y derecho

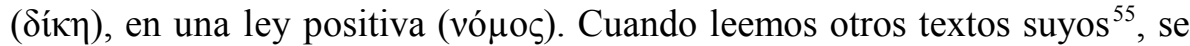
observa de manera manifiesta su deseo; pretende hacer de intermediario entre los nobles y el pueblo, conteniendo a unos en sus privilegios y aliviando al pueblo y mejorándolo por medio del establecimieno de unas leyes. Él es el soberano que traslada la fuerza de su poder a la ley,

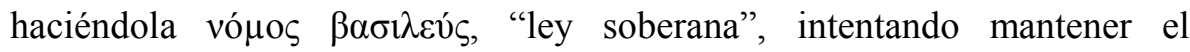

convivencia lo disfrutan todos. Y dice Eliano introduciendo una cita de Eurípides (fr. $920 \mathrm{~N}$ ): "No fue Solón quien impone a los leones este comportamiento, se lo enseña la naturaleza, 'a

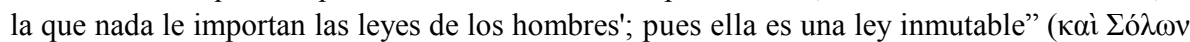

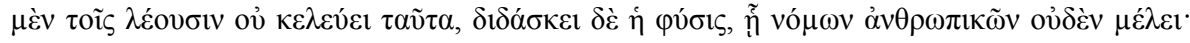

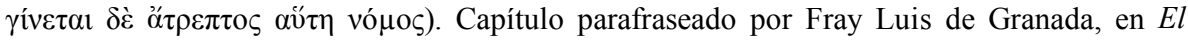
simbolo de la fe ( $1^{\mathrm{a}}$ parte, cap. XIV 2).

53 Cf., A. García Calvo, Razón común. Edición crítica, ordenación, traducción y comentario de los restos del libro de Heráclito, Madrid, 1985; fr. 1 (D-K 1): «Esta razón ( $\tau$ õ $\delta \varepsilon \lambda$ óyov), siendo ésta siempre como es, pasan los hombres sin entenderla, tanto antes de haberla oído como a lo primero después de oírla: pues, produciéndose todas las cosas según esta razón, parecen como faltos de experiencia, teniendo experiencia así de palabra como de

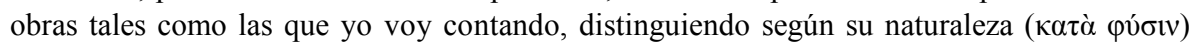
cosa por cosa y explicando qué hay con ella», pp. 32-36.

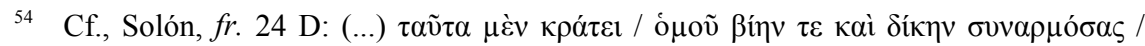

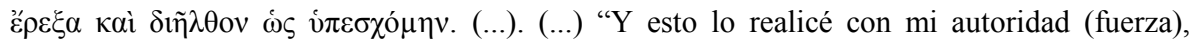
armonizando a la vez violencia y justicia, y llevé a cabo lo que había prometido. (...)”, Líricos Griegos Arcaicos, ed. bilingüe, por J. Ferraté, Barcelona, 1968, pp. 87-88.

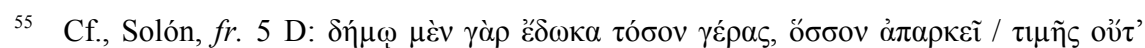

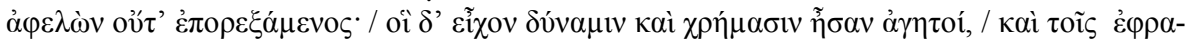

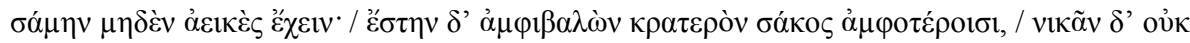

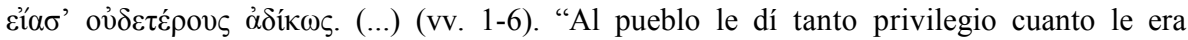
suficiente, sin quitarle de su dignidad ni añadirle. Y de los que tenían poder y eran notados por ricos, también de estos me cuidé que no sufrieran afrenta. Enarbolando mi fuerte escudo me mantuve entre unos y otros y no les dejé vencer a ninguno de los dos bandos injustamente", Líricos Griegos Arcaicos, ob. cit., pp. 75-76. 
equilibrio y la paz social ${ }^{56}$, creando un Estado de derecho, proceso previo para llegar a alcanzar la democracia en el s. V a. C. La violencia (naturaleza) y la justicia (cultura, derecho existente) han de someterse a la ley positiva, la ley dictada por Solón, ahora hecha soberana. De quien se dice incluso, que, una vez que dictó leyes, se ausentó de la patria con el ánimo de que así fuese la ley la máxima autoridad.

Una formulación similar, pero con muy diferente significado, la encontramos, en el s. V a. C., en Píndaro en su famoso fragmento en que canta la soberanía de la ley:

La ley de todos soberana, de los mortales y de los inmortales, guía justificando el extremo de la violencia con mano muy poderosa. Lo infiero por las hazañas de Heracles $^{57}$.

Píndaro es más radical en la definición; soberanía de la ley que lo es sobre mortales e inmortales. Parece formular la soberanía del vó ${ }^{\circ} \varsigma$ reconociendo como justo la violencia. Se podría, tal vez, interpretar y traducir el texto con otro sentido: “(...) (la ley) dirige con mano poderosa castigando lo más violento". Pero no parece permitirlo el significado del texto que sigue, en el que se refiere a las hazañas de Hércules, al robo violento de las vacas de Gerión. Es más, Píndaro dice: "Y lo conjeturo ( $\varepsilon \kappa \mu \alpha i ́ p o \mu \alpha$, 'tomo como indicio', 'juzgo') por las hazañas de Heracles".

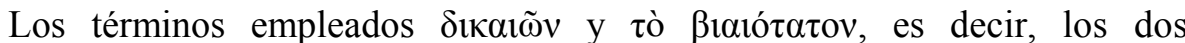

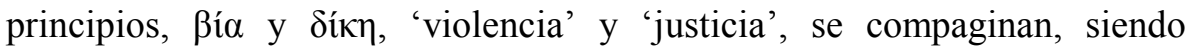
antitéticos para los griegos ${ }^{58}$. La extrema violencia, en Píndaro, se articula dentro de la ley que ejerce el poder soberano con mano muy poderosa. Llama más la atención el texto de Píndaro, si recordamos el de Hesíodo, en el que la ley (vó $\mu \circ)$ es el poder que separa violencia y justicia, es decir, que

56 Le preocupa que no se vigilen y cumplan los fundamentos augustos de la Justicia, negligencia que origina el desequilibrio entre las clases y trae consigo discordias internas y

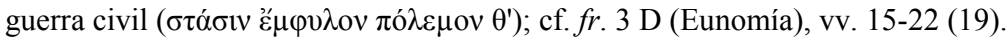

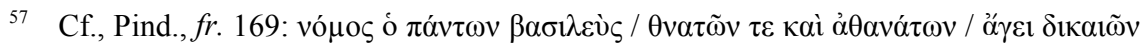

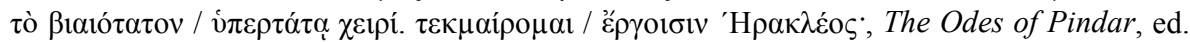
por J. Sandys, Londres, 1957, p. 604. Cf. un comentario en los capítulos 2 y 3, «Nómos Basileús», y «Potencia y derecho», por G. Agamben, op. cit., pp. 45-55 y 56-67, respectivamente.

58 Platón trata de superar esa antítesis, ese debate entre naturaleza y derecho, véase en libro X de Las Leyes. 
separa mundo animal del mundo humano ${ }^{59}$. En Píndaro, en cambio,

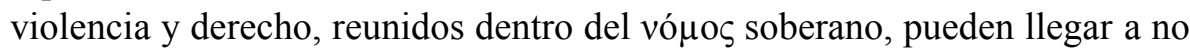
diferenciarse, quedan confundidos dentro de la ley. La soberanía parece, en él, incorporar el estado de naturaleza en la sociedad, o de otro modo formulado, como un umbral de indiferencia entre naturaleza y cultura, entre

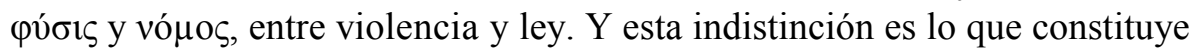
la violencia soberana específica ${ }^{60}$. Es, probablemente, la primera formulación de la soberanía de la ley que permitirá toda acción al que ejerce el poder en nombre de la ley. Es la ley positiva que es justa y conlleva violencia. Y de ahí se puede entender que los sofistas, más tarde, se refieran a la ley (vó $\mu \circ \varsigma)$ como el tirano de los hombres, ya que les fuerza a muchas cosas en contra de lo natural ${ }^{61}$.

59 En Hesíodo (véase el texto en nota supra). la ley impuesta por Zeus a los hombres: "es que los animales (peces, fieras y aves voladoras) se coman los unos a los otros, ya que no existe justicia entre ellos, a los hombres, en cambio, les dio Zeus justicia que es mucho mejor".

${ }^{60}$ Cf., G. Agamben, Homo sacer, ob. cit., pp. 49-51. Este autor sigue analizando las consecuencias de la definición de Píndaro en las teorías modernas sobre el estado de derecho y el estado de naturaleza, llegando a tesis de la soberanía como decisión sobre el estado de excepción (pp. 93-150).

${ }^{61}$ P1., Prot. 337c-d; Leg. 690 d ss.; Platón cita el fr. de Píndaro (véase supra) en

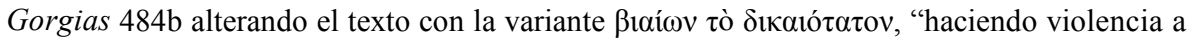
lo más justo"; la variante del Gorgias, en boca de Calicles, no cambia el sentido profundo de la frase. Sin embargo, en otras citas, Platón no cambia el texto de Píndaro; así en Leyes III

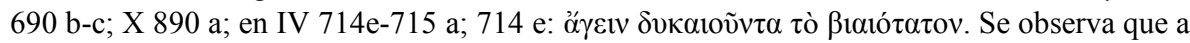

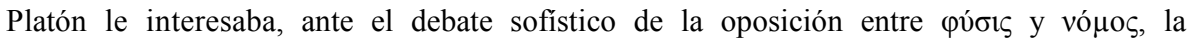
coincidencia de violencia y derecho que constituye la soberanía. En cambio, en el pasaje de las Leyes (714e), el poder de la ley se define como conforme a la naturaleza y esencialmente

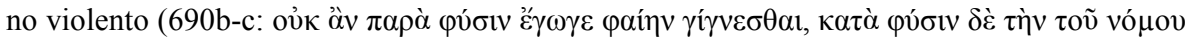

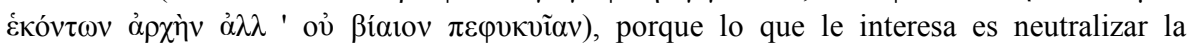
oposición que tanto para los sofistas como para Píndaro, aunque de manera diversa para éste

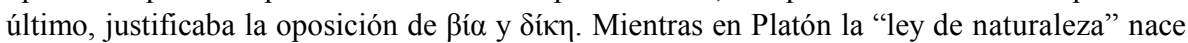

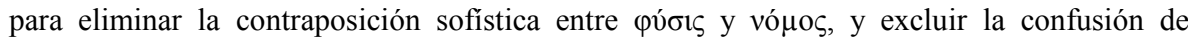
violencia y derecho, en los sofistas - y de modo diverso en Píndaro -, la oposición sirve

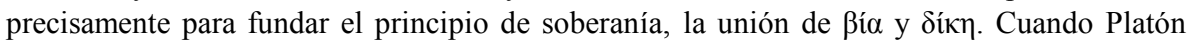
dice que la ley debe reinar sobre los hombres y no los hombres sobre la ley, parece que no pretende afirmar la soberanía de la ley sobre la naturaleza, sino simplemente su carácter "natural", es decir no violento. La ley es "natural" porque el alma existe - con más razón que todo lo demás - por naturaleza (cf. Leyes X 892 a-892 c). Cf. Agamben, Homo sacer, ob. cit., pp. 50-51. He citado a Platón por la ed. de R. G. Bury, Laws I-II, The Loeb Classical Library, London, 1984. 
Después de un largo camino, como hemos visto, se llega a la debatida contraposición de esos dos términos, en los tiempos de la Sofística y en el

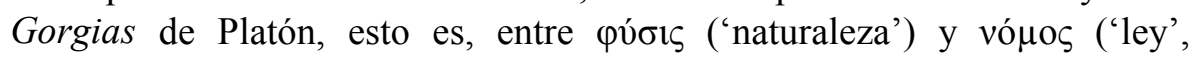
'convención'), siendo entonces conceptos incompatibles y objeto de fuertes enfrentamientos dialécticos sobre cuál debía predominar ${ }^{62}$. En el estoicismo, sin embargo, también en los epígonos de los estoicos, y en Eliano, observamos cómo se fue llegando a una identificación de ambos conceptos, - ya Platón lo había intentado de modo diverso. La ley natural, para los estoicos de la época imperial, es la ley moral por la que deben guiarse los seres humanos, es la que regula los valores morales, es el más elevado fuero de la ética, y es firme y eterna. De muy diferente manera que en Píndaro y que la ley, al modo platónico (Leyes $\mathrm{X}$ ), que debe reinar sobre los hombres y no los hombres sobre la ley, la ley natural divina, es decir, el lógos universal que impregna a todos los seres, es para los estoicos de alguna manera la ley soberana.

En la obra de Eliano encontramos la oposición entre la ley positiva de los hombres, contingente, y la ley natural, inmutable, a la que deben someterse todos, los seres humanos y el resto de los animales; los irracionales siguiendo su instinto la acatan, los hombres siguiendo el mandato de su razón. Y al comparar la actuación de unos y otros, con cierta ironía, pesimismo, o escasa resignación, reprocha, o ridiculiza la conducta de los seres humanos debido a su libre albedrío, precisamente por utilizar su $\lambda$ ó ignorante, apartado de la Naturaleza. Su exhortación es a que la ley de la Naturaleza, el $\lambda$ ó $\gamma_{0} \varsigma$ divino, se convierta en ley de los seres humanos, en el vó $\mu$ o $\varsigma$ de la vida de los hombres; a que la ley de la Naturaleza se haga fuente de moralidad, y se una o confunda con la ley positiva. La ley de la Naturaleza es la que, para él, debe ser "soberana".

Se podría ver, como antecedente de su pensamiento, repito, el elevado canto poético de Cleantes a Zeus. También Cleantes cuando celebra la obediencia de todos los seres, espontánea o forzada, a la ley universal, en su Himno a Zeus, emplea una formulación religioso-filosófica y ética, plena de preocupación moral por el comportamiento de los seres humanos: "Sin ti, dios, nada se hace sobre la tierra, ni en el éter divino del cielo, ni en el mar, salvo lo que urden los malvados en su demencia”. Y sigue cantando esa Ley,

62 Calicles en el Gorgias (483e) de Platón empleaba, con toda intención, esta expresión

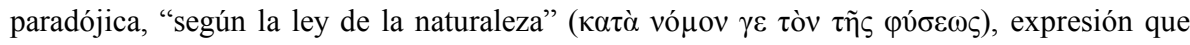
reunía los dos conceptos incompatibles en aquella época. 
identificada con Zeus, que tiene poder sobre los opuestos, sobre el bien y

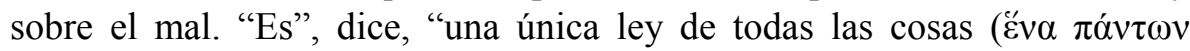

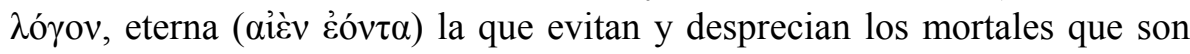
malvados, infortunados, que, deseando sin cesar la posesión de los bienes, ni miran a la ley común a todos de dios $(\theta \varepsilon$ oṽ kotvòv $\lambda$ ófov)ni la escuchan, mientras que si la obedecen con inteligencia ( $\sigma \grave{v} v \vee \tilde{\varphi})$ podrían tener una vida

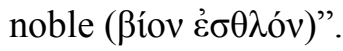

Juzgando los acontecimientos particulares en función del conjunto, probablemente se entreveía una solución al problema del mal. Platón en las Leyes ya formula la necesidad del predominio del Todo sobre las partes. La resonancia de estas ideas, transferidas al s. II-III d. C., es la que se puede intuir en el fuero interno de Eliano; en la época en que vive el prenestino se agiganta el pesimismo y se ennegrecen las tintas con referencia al comportamiento de los seres humanos, aunque no es menos importante la descripción negativa que Cleantes, en el s. IV-III a. C., hace de la conducta humana

Esta formulación que expresa tan convencido, a modo de auténtica súplica, en la que hay un $\Lambda$ ó ${ }^{\circ}$ (Ley) eterno que impregna todo el cosmos, no cabe duda, está sirviendo de base para establecer la coordenada mental que iguala a todos los seres, bajo el punto de vista de que todos se someten o deberían someterse a ella; y con este modo de conducirse estarían cumpliendo su propio fin; éste era el ideal de la moral de los seres vivientes para los estoicos y también para Eliano.

\section{Cualidades morales de los irracionales en los estoicos y en la obra de Eliano.}

En la época imperial el aspecto ético adquiere un relieve enorme, y el interés por la Naturaleza no sólo es motivado por la curiosidad científica, sino también por necesidades espirituales, como fortalecimiento del alma. La ciencia en la filosofía estoica se basa en el conocimiento de la Naturaleza en la que está impregnada la Razón universal.

Los estoicos, al identificar ley moral con ley de la Naturaleza, funden ética y física; sólo la Naturaleza es capaz de determinar lo que es o no moral. El estudio de la Naturaleza, por tanto, siempre les interesó, y fieles a su teoría del Lógos, el objeto de su investigación puede abarcar todos las grados del ser. Basta pensar en Zenón con sus tratados, Del Universo, Sobre 
las pasiones, República; en Crisipo, Sobre el vacío, Sobre las ciencias fisicas; Posidonio con interés científico amplio, en meteorología, biología, astronomía, sobre el océano (Sobre los meteoros; Sobre el océano y las cosas concernientes; Sobre la magnitud del sol; Tratado de Física); en Séneca (Cuestiones naturales), en Plinio el Viejo (Historia Natural), en Manilio (Astronómica, en polémica con Epicuro y con Lucrecio), en Cleomedes (Manual de Astronomía), y otros. Fundan su imperturbabilidad y firmeza en la comprensión de la Naturaleza cósmica y humana, la aceptación de la ley natural y la idea de una nueva polis universal, la "cosmópolis", que siendo natural, sea también "política" (civilizada, social, supraindividual) y de la que el individuo se sienta orgánicamente parte.

La Naturaleza mantiene el mundo unido, cuyas partes están en cohesión, actuando unas sobre otras; hace crecer las plantas y es causa de la racionalidad de los seres humanos. Pero es una Naturaleza que los fundadores del estoicismo y sus primeros seguidores - pasajes de Crisipo (ca. 277-208 a.C.) lo testimonian -, la presentan dividida claramente en el mundo del hombre y el de todos los demás seres. Así lo cantan los versos de Cleantes, arriba citado (vv. 3-5). Entre todos los seres que viven y se mueven sobre la tierra (v.5), los seres humanos son los únicos que han nacido con el don de la palabra (v. 4); y la comunidad de los hombres se

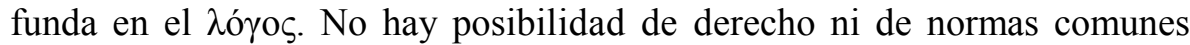
entre quienes poseen la razón y quienes están privados de ella ${ }^{63}$ En los animales existe una forma de inteligencia, pero es una inteligencia instintiva ( refieren a los instintos de los animales que sirven para preservar su constitución y dan la impresión de ser impulsos racionales. El cosmos, dice Crisipo, "es un sistema constituido por los dioses, los hombres y las cosas creadas para ellos".

Este antropocentrismo típico de la Estoa no es compartido por alguno de sus representantes más notables. Se observa dentro del estoicismo una influencia de la ideología cínica, como resultado de una época de crisis y decadencia moral. La doctrina cínica propone un retorno a la naturaleza y un rechazo de las convenciones de la cultura, y toman como ejemplos de

\footnotetext{
${ }^{63}$ Cf., Diog. Laerc. VII, 129: "Además, tienen por verdad indiscutible que no tenemos nosotros ninguna obligación de justicia hacia los demás animales debido a su desigualdad respecto de nosotros, como afirman Crisipo en el libro primero de su tratado Sobre la justicia y Posidonio en el libro primero de Sobre el deber"; cf. también Cic., De finibus III 20, 67.
} 
comportamiento a los animales; faceta ésta que nos interesa poner de relieve. Los cínicos heredan el ideal socrático de buscar, ante todo, la virtud, de someter todo producto de la cultura a crítica, de esforzarse por la conquista de la autosuficiencia mediante el ascetismo y el autodominio. Sabemos que del cínico Crates es discípulo Zenón el fundador de la Estoa. Esta interconexión entre ambas doctrinas, de base socrática, y los pensadores de ambas ideologías, puede explicar, parcialmente, esas grandes diferencias entre los seguidores de la Estoa, y los vínculos de algunos a ideas marcadamente cínicas, y en particular con referencia a la opinión que les merecen los animales.

El filósofo de la Academia media, Carnéades (ca. 215-129 a. C.), combatió los argumentos, principalmente del estoico Crisipo, negando que los animales fueran creados para utilidad del hombre. Plutarco, en sus obras sobre la psicología de los animales, combate a la Estoa y refuta la tesis de que el derecho sólo puede regular las relaciones entre los hombres (994 c);

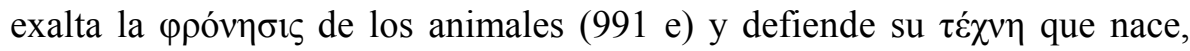
dice, de la necesidad y nunca del capricho o de la vanidad como ocurre en la conducta de los seres humanos. Eliano, probablemente muy influido también por Plutarco, es bastante ortodoxo con esa doctrina cínico-estoica originaria y conecta, a la vez, con la epicúrea, y con la estoica de la época imperial. De acuerdo con el pensamiento de su época y con las circunstancias históricas, el asunto de la falta de moral de la sociedad le preocupa y se transluce en toda su obra; hasta tal punto que, aunque se interesa por las explicaciones científicas, las búsquedas especulativas se orientan hacia la moral, o bien pueden quedar relegadas si le resulta especialmente interesante la conducta del animal que estudia. Para Eliano, de manera semejante que para el estoico del Imperio, el mundo está pletórico de lógos divino, y esa fuerza divina la proyecta hacia las alturas del lógos cósmico, a la vez providencia, orden indefectible. Por otro lado, el

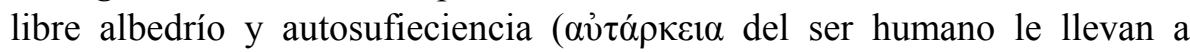
actuar de manera errónea por ignorancia, y, en esta trayectoria, son los animales, privados de la libertad propia del ser humano, los que mejor cumplen su fin, los que se comportan según la ley de la Naturaleza, es decir, de acuerdo con el lógos universal, y, por tanto, de acuerdo con la moral. De ahí esa búsqueda de fuentes seguras de moralidad para el ser humano concordes con la Naturaleza, con la Ley universal que la rige. Un desarrollo más amplio de este proceso ideológico, se puede decir que llevaría al 
desplazamiento - y se deja vislumbrar, aunque de manera inconsciente -, en Eliano, de un antropocentrismo a un cierto biocentrismo, en términos modernos.

Me parece interesante observar de qué modo Eliano sigue la doctrina estoica y qué cualidades humanas y virtuosas de los animales considera importante destacar y dar a conocer. Nos ayudará a ello, primeramente, partir de algunas consideraciones del propio autor acerca del carácter de su obra y su método. Y, en segundo lugar, siguiendo muy de cerca el texto de su tratado, analizaremos qué aspectos son los que tiene en cuenta en esa confrontación entre el comportamiento de los animales y de los seres humanos.

Sobre las peculiaridades de los animales se podría definir en cuanto a su contenido, de manera superficial, como colección de notas curiosas extraídas, en su mayor parte de otros compiladores, buscando en los animales sentimientos humanos. Pero es mucho más que esto. Prestemos oídos al propio autor en cuanto a su método, sus fines y los propios contenidos. Es el mismo Eliano quien se pone en lugar de los críticos futuros de su obra ${ }^{64}$ justificando su aparente falta de coherencia y mezcla de especies de animales y propiedades ${ }^{65}$. Puso, dice el autor, diligencia, reflexión y esfuerzo para el aumento del saber y tuvo en cuenta todo lo que el progresivo avance en estos estudios había permitido descubrir, gracias a las investigaciones contrastadas por la experiencia de otros estudiosos amantes del saber, quienes con una inteligencia cultivada y dueña de vastos conocimientos habían dado a conocer las cacterísticas específicas de cada uno, y habían mostrado cómo los demás seres vivos suscitaron un interés no menor que el hombre ${ }^{66}$. Eliano confiesa su deseo ardiente, peculiar e innato

64 Ael., NA, Epilog.: "Sé también que algunos no aprobarán el que no haya tratado, separadamente, cada uno de los animales y que no haya dicho, de una sola vez, todas las características de cada uno, sino que mezclé de manera variada las variadas clases de animales al describir tan gran número, y que unas veces abandoné la narración sobre algunos, otras veces retrocedí para añadir otras características de su naturaleza”.

65 Ael., NA, Epilog.: "Creí necesario, aparte de seguir mi propio juicio y no el de otros, tejer y entretejer este escrito con la variedad de mis lecturas, evitando lo prolijo en relación a los animales y el aburrimiento producido por la monotonía, como si fuese un prado o una bella corona de muchos colores, en el que los numerosos animales aportasen su contribución de flores".

66 Ael., NA, Epilog. y Prolog. 
de conocimiento ${ }^{67}$; deseo que le ha llevado a ser exhaustivo en la recogida de material para componer esta obra, sin omitir nada ${ }^{68}$, y es más, añadió algunas características que otros expertos estudiosos no habían mencionado $^{69}$, y ha querido redactarlo y difundirlo en un lenguaje coloquial $^{70}$, en griego. Eliano, romano bilingüe, que vive (ca. 170 d. C. - 235 d.C.) en una época en que Grecia ya es provincia romana, con gran admiración por la cultura griega antigua, es quizá el principal escritor en griego de su generación ${ }^{71}$. Su obra, como él mismo dice, pretende que sea merecedora de atención por la amplitud de la investigación y por su lenguaje $^{72}$, no sólo pretende expresarse en un estilo cuidado, según la corriente aticista, sino, a la vez, por darle un carácter divulgativo a la obra. Y si aprecia la verdad en otros campos del saber, sigue diciendo, mucho más en esta disciplina. Al modo de Tucídides ${ }^{73}$, Eliano desea que su obra sea útil para la Humanidad y la considera como un tesoro nada desdeñable ${ }^{74}$. Sin embargo, a diferencia de Tucídides que es única fuente literaria (con exclusión de unos capítulos de Diodoro, XII 36-XIII42) del período de la historia que trata (432-411 a. C.), Eliano tiene muy en cuenta lo que han escrito los científicos que le precedieron y compiladores previos, aunque su aportación no es pequeña en el campo científico y en otros muchos. En ambos autores, su obra adquiere una utilidad didáctica, y debemos añadir que los dos pretenden unos fines morales, abiertamente expuestos con gran frecuencia por Eliano. El carácter racionalista y la voluntad de objetividad

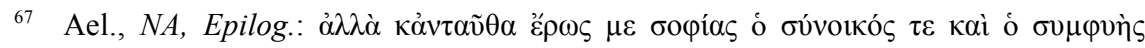

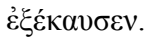

68 Ael., NA, Epilog.

69 Ael., NA, Epilog.

70 Ael., NA, Prolog.

71 Cf., Philostr., Vitae Sophistarum II 31, 624-625.

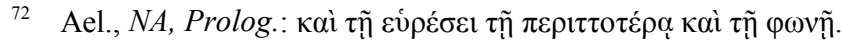

73 Thuc., I 22.

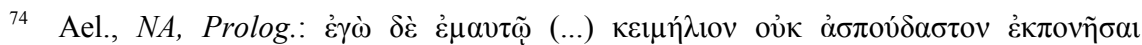

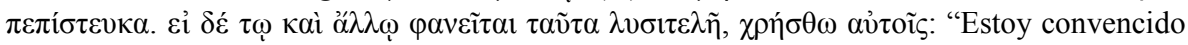
de que mi trabajo hecho con esfuerzo es un tesoro nada desdeñable. Si le parece útil a alguien, sírvase de él". El tono y estructura de las frases y algunos términos empleados por

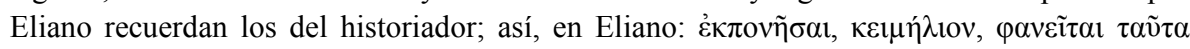

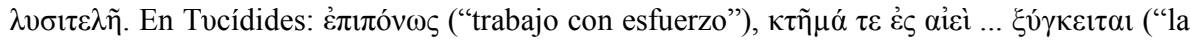

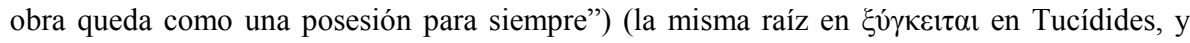

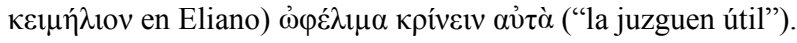


de la obra de Tucídides no es comparable a la de Eliano, son fruto ambos de las corrientes de pensamiento de la época en que les toca vivir; las circunstancias económicas, sociales, políticas y personales condicionan y marcan el pensamiento y la obra de cada uno. Sin embargo, Eliano, como el historiador, confiesa su afán de objetividad: es "amante del saber y ardiente seguidor de la verdad"; dice: "yo he preferido contar lo que ví con mis ojos y lo que otros contaron como cosas sucedidas (...), recopilando unos cuantos del cúmulo de hechos que, no en pequeña medida, demuestran las singularidades del animal" (II 11) (cf. Thuc. I 22). No es nuestra intención ni parece pertinente comparar ambas personalidades, tan diferentes, sólo aludir al deseo de Eliano de parecerse a Tucídides, deseo que se vislumbra a través de la declaración de intenciones que hace en cuanto al método. Ya tuvimos ocasión de mencionar a ambos juntos a propósito de la fundamentación de la acción de los hombres.

La investigación de los animales del prenestino trata, principalmente, de la conducta natural de estos seres, de sus costumbres y comportamiento, de etología y ecología animal y comparada con frecuencia con la de los seres humanos. Comienza el Prólogo destacando los dones con que la Naturaleza adornó al hombre y considera más relevante que también los animales privados de razón posean por naturaleza cualidades positivas y "hayan obtenido en suerte junto con el hombre muchas y admirables prerrogativas de los humanos" ${ }^{75}$. Le parece cosa muy meritoria indagar y seguir las huellas de los dones con que la Naturaleza los dotó ${ }^{76}$. De manera manifiesta declara su sentimiento de admiración hacia aquél que investiga y saca a la luz las facultades de tantos animales. Tiene bien presentes los estudiosos anteriores de este tema animal, las citas y fuentes muestran bien su deuda con la investigación que le precedió. A Aristóteles, bien de manera directa, o bien sirviéndose de compiladores, lo cita más de cincuenta veces, y la propia materia y el título de la obra de ambos, Investigación sobre los animales - la de Aristóteles -, y Sobre las peculiaridades de los animales traducción literal del título de la de Eliano -, hacen del estagirita uno de los autores que pudo admirar y tener más en cuenta ${ }^{77}$, si bien no se nos oculta

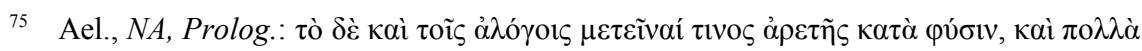

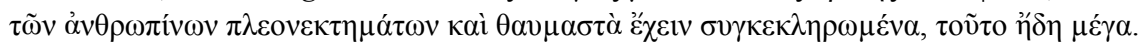

76 Ael., NA, Epilog. (final).

77 La zoología nace con Aristóteles con sus obras sobre la esfera animal: Investigación sobre los animales (Historia animalium), Sobre las partes de los animales (De partibus 
que el enfoque y los intereses de ambos son bien diferentes. El prenestino, de manera tal vez no muy consciente, en su objetivo primario, está sirviéndose también de doctrina de la ética aristotélica, del engranaje de la acción animal que se convertirá en acción moral, como hemos expuesto arriba.

Eliano desea llevar más adelante lo que otros investigadores ya habían hecho progresar en gran manera ese tema animal para su tiempo, de ahí su exhaustividad en la recogida de material. Con plena convicción considera su obra como un tesoro para los seres humanos y no es sólo porque la considera una compilación completa, sino por la impronta personal; el sello que añade y con que impregna ese material es tan importante, para él, como el propio material. Y quizá lo expresa en la frase más emotiva y, si se quiere, más dramática que sale de su alma. Una nota de amargura, muy elocuente, que deja caer el autor en el Epílogo, fruto de la experiencia que recoge de su época, de la degradación moral y decadencia de las costumbres. Dice: "me siento profundamente disgustado de que mientras exaltamos la piedad de los animales carentes de razón, tengamos, a la vez, que censurar la impiedad de los seres humanos" ${ }^{78}$. Ese sentimiento, dolido y no resignado, expresa, de alguna manera, su espíritu religioso y de fuertes convicciones morales. Pretende, por tanto, como objetivo primario, aleccionar a los hombres que no saben cumplir con su fin propio dentro de la Naturaleza, fin que los irracionales observan con su conducta; eneñarles a reconocer ese $\lambda$ ó $\gamma o \zeta$ divino racional cósmico, impreso en todos los seres. Es ese contar las cosas del mundo animal como son y que coinciden de manera ejemplar con cómo deben ser. Coincide lo real y lo moral. Desea moralizar el mundo real de los seres humanos. Se deduce, a partir de los textos, que hay una especie de manipulación de las fuentes para resaltar la ejemplaridad

animalium), Sobre la marcha de los animales (De incessu animalium), Sobre el movimiento de los animales (De motu animalium), y Sobre la generación de los animales (De generatione animalium). Estos tratados enlazan bien con temas estudiados en los Pequeños tratados de historia natural (Parva naturalia) y Acerca del alma (De anima). Sobre las fuentes de Eliano, cf. las Introducciones de las ediciones y traducciones citadas de la obra; principalmente, la Introducción de J. M M $^{\mathrm{a}}$ Díaz-Regañón López, ob. cit., pp.11-15; J. Vara Donado, ob. cit., pp. 13-16; F. Maspero, ob. cit., pp. 19-24.

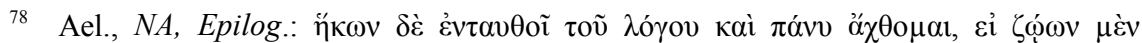

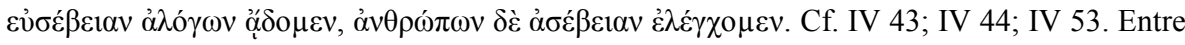
otros muy frecuentes pasajes con este pensamiento pesimista. 
moral que pretende inculcar con su obra ${ }^{79}$.

El poner de ejemplo a los animales es el elemento básico para cumplir con su objetivo. Es pasar de la acción y la conducta animal a la vida real de los humanos, a su comportamiento falto de moral. Precisamente en su obra la comparación entre las cualidades y la conducta del hombre y la de los animales funciona como un elemento estructural en la mayor parte de los capítulos, y de esa confrontación salen ganando siempre los animales. No comparte con los fundadores del estoicismo la separación tajante entre los seres humanos y el resto de los animales, basada en la presencia del lógos y en la dotación del lenguaje de los primeros. Es verdad que reconoce de manera manifiesta en el Prólogo esa dotación divina de los humanos (v. supra), pero a renglón seguido considera más relevante y digno de admirar que también los animales privados de razón tengan por naturaleza muchas y admirables cualidades de los humanos ${ }^{80}$.

Para Eliano, la vida, la experiencia, el conocimiento de la conducta de los seres humanos le hacen defender la tesis opuesta a sus propias creencias. Una cosa es la teoría y otra la praxis. El $\tilde{\eta} \theta$ o $̧$ no brota de la reflexión sino se solidifica en las obras, como hemos dicho. Eliano parte justo de las acciones de los animales para recuperar, corregir la moralidad entre los hombres. Y este es el fin principal que impregna toda su obra; con cierta ironía, se puede decir que ese fin es como el lógos que impregna la naturaleza; pero para el prenestino, ese cumplir de manera perfecta en la naturaleza con sus propios fines (principio estoico) está en posesión de los irracionales. Este será el principal razonamiento de Eliano, que le hace seguir, en ocasiones, de manera poco rigurosa $\mathrm{y}$, en otras, con abierto distanciamiento, la doctrina estoica ortodoxa sobre muy variados aspectos; concibe esa vuelta a lo natural, más en consonancia con la doctrina cínica.

Pasemos a un examen más detallado de las cualidades de los irracionales en su obra De natura animalium.

79 En las notas a pie de página de las ediciones y traducciones de la obra se hace notar, en cada caso, las variantes de las fuentes ocasionadas adrede por Eliano, con afán moralizador.

80 Cf., entre otros, 2, 11; trata de resaltar en ellos sus hábitos, sus formas, la sagacidad, su pronta inteligencia, la justicia, la templanza, la valentía, el afecto, la piedad: Ael., $N A$,

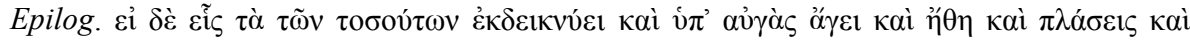

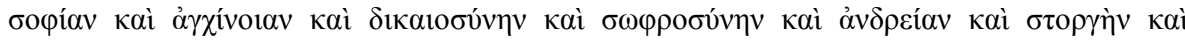

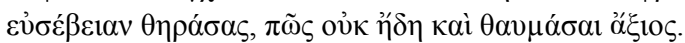


Como hemos dicho, no está de acuerdo (VI 50) con la tesis de Hesíodo ni tampoco con los estoicos - cuando el poeta afirma que los dioses separaron en dos las diferentes especies de animales, porque sólo dieron a los hombres la capacidad de actuar con justicia ${ }^{81}$. De ahí se deduce que

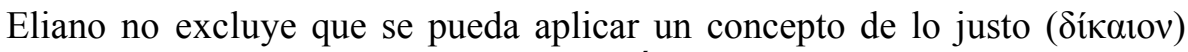
también con referencia a los animales. Éstos recuerdan ofensas (IV 35), y aplican la venganza justa ${ }^{82}$.

Cuando afirma que los animales gozan de la benevolencia de los dioses (VII 2; XI 7; VII 31; 35; XIII 1), considera también que sufren castigo cuando cometen un crimen, según la justicia divina que regula el universo (XII 32; cf. XI 19; XIII 23). En consecuencia, las acciones de los animales son consideradas dignas de alabanza o de desaprobación de parte de la divinidad; así, son premiadas las cigüeñas por la piedad que muestran hacia los progenitores, mayor que la de todos los hombres (III 23); y es castigada la serpiente que mata a una persona (XII 32).

No están excluidos tampoco de toda forma de derecho. Los animales

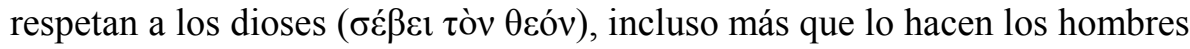
que confiesan y hacen gala de su ateísmo, como Hipón de Samos, Diágoras de Melos, Heróstrato de Éfeso (VI 40) ${ }^{83}$.

El respeto a los ancianos - dice Eliano - lo legisló Licurgo; pero no puede competir la ley de los hombres (Licurgo, Solón, Zaleuco y Carondas), con las leyes de la Naturaleza: "la raza de los elefantes obedece a unas leyes que los códigos humanos ni siquiera han previsto: se privan del alimento en favor de los más viejos, se cuidan de los que están débiles por la edad, los preservan de todo peligro, los sacan de los hoyos si se caen (...)". Dice

81 Véase supra, comentario al pasaje de Hesíodo y la cita de E. Lledó.

82 Cf., Ael., NA 3, 21; "Justicia, dice Eliano, utiliza a los animales como colaboradores" (XI 19); ellos saben castigar el fraude (VI 52). Y los ratones temen de alguna manera la cólera divina (VI 41).

${ }^{83}$ Hipón de Samos es un filósofo pitagórico del s. V a. C., satirizado como ateo; Diágoras de Melos vive en el s. V a. C., conocido por sus ataques a la religión de los atenienses; Heróstrato de Éfeso incendió el templo de Ártemis en el 356 a. C. Hay otros pasajes con una actitud respetuosa de parte de los animales hacia los dioses, IV 2; VI 40; X 50; XI 1, 4, 7; XVI 16; muchos son sagrados y dedicados a alguna divinidad, VII 45; VIII 12; X 24, 29, 31, 46; XI 2, 10, 11, 17, 20, 33; XII 1, 2, 11; XVII 1, 46; los seres humanos veneran a algunos animales, X 45; XI 17, 31; XII 40. Manifiesta también cómo las numerosísimas víctimas animales de los sacrificios, en el templo de Afrodita en Erice, aceptan voluntarias, requeridas por la diosa, ser sacrificadas, X 50; XI 4. 
irónicamente Eliano y a la vez de manera pesimista: “¿Cuándo un elefante apaleó a su progenitor? ¿Cuándo, entre ellos, un padre desheredó a un hijo? (...)" (VI 61). Hay algunos otros pasajes que indican ese mismo sentimiento respetuoso (VII 15; VII 17; XII 6). Critica el comportamiento criminal del hombre, para con los delfines, animales dotados de gran piedad y muy queridos por las Musas, hijas de Zeus (XII 6); los cuales muestran también estima con sus muertos, y en esta conducta, dice, aparecen como superiores a los atenienses que no se avergonzaron de dejar insepulto a uno de sus conciudadanos distinguidos, a Foción. La piedad y el sentido religioso acusado de Eliano se expresa en estos pasajes y en algunos otros (II 4; III 23; VI 40; XII 36); los animales pueden llegar a descubrir incluso robos sacrílegos (VII 13; X 26).

Con referencia a la noción de la Providencia, los estoicos ofrecen, en esta faceta, instrumentos a la teología y a la teodicea del cristianismo. Eliano, al hablar de los elefantes (VII 44), dice que saludan religiosamente el nacimiento del sol, demostrando de este modo que son respetuosos ( $\pi \rho 0 \sigma \kappa v v o \tilde{v} \sigma \mathrm{v})$ con esa divinidad, mientras los hombres se interrogan si hay dioses y, en caso de que existan, si se preocupan de nosotros; parece criticar en este pasaje, sin nombrarlos, a los epicúreos que negaban la existencia de la Providencia y fueron objeto de duros ataques por ello de parte de los estoicos ${ }^{84}$.

Una institución muy defendida por Eliano es la del matrimonio, aunque él no se casó según nos dice Filóstrato, y parece que fue una elección personal, ya que su cargo de pontífice máximo en su época, y mucho antes, no impedía casarse ${ }^{85}$. Dentro de la moral estoica, el sabio debe insertarse en la sociedad, casarse y tener hijos. El matrimonio y educar a los hijos es un deber cívico; el adulterio es un delito contra la colectividad humana. Eliano parece de acuerdo con estas ideas: condena el adulterio sin discriminación y

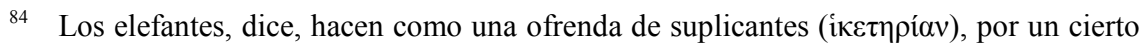

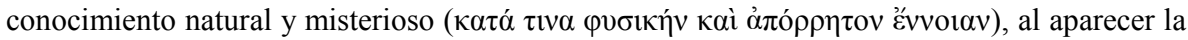
luna nueva $(4,10)$; el gallo salta y se entusiama cuando sale la luna, y canta cuando se levanta el sol $(4,29)$.

85 Cf. Philostr., VS XXXI 625: "Vivió más de sesenta años y murió sin hijos, pues rehusaba tenerlos por no haberse casado". Sobre el cargo de pontífice máximo, sus funciones y evolución de la magistratura en la vida romana, cf., entre otros, J. Guillén, Urbs Roma. Vida y Costumbres de los Romanos. II. La Vida Pública, Salamanca, 1978, pp. 193-195. 
narra episodios en que los animales lo descubren y lo castigan ${ }^{86}$; la fidelidad en la pareja es ejemplificada con el pez-Etna (I 13), capaz de respetar con todo rigor los deberes conyugales; en cambio, los hombres con unas leyes nobles y venerables, comenta con gran sarcasmo, libertinos como son, no se avergüenzan de transgredirlas. Deja bien clara la oposición entre la leyes de la naturaleza inculcadas en todos los seres, cumplidas de manera perfecta por los irracionales, en contraposición a las leyes positivas de los hombres que son vanas al ser quebrantadas. Hay otros ejemplos de animales que forman parejas perfectas de mutua fidelidad (las palomas, III 5; las cornejas, III 9); la templanza sexual la ejemplifica en las palomas torcaces, y llevada a un extremo en las tórtolas (III 44); amor desinteresado y mutuo entre la pareja es el del mirlo marino (I 15); el prenestino ataca el comportamiento lujurioso (I 2; I 12; III 16; III 17; IV 16); alaba la moderación (I 13; VI 1; VIII 17); en referencia al incesto, considera que hasta un irracional lo evita, y de manera natural lo advierte y lo rechaza ${ }^{87}$. El pudor es también sentimiento de los animales (VI 60, el camello), así como los celos (III 42; VI 42; IX 63; X 1). La opinión del autor, en el campo de la sexualidad, está de acuerdo con el ideal del sabio, según las doctrinas cínica y estoica, de autocontrol o dominio de sí mismo, y con su cargo de sumo sacerdote muy convencidamente ejercido; se le nota cierto escrúpulo a usar términos corrientes de las funciones de carácter sexual, como se ve en I 14; II 35; VI 64; VIII 17; IX 39, entre otros.

La virtud ( $\alpha \rho \varepsilon \tau \eta ́)$, igual que el vicio, en el plano teórico, se predica tanto para el hombre como para la mujer. El estoico Cleantes escribió un tratado con el título La virtud de los hombres y de las mujeres es toda una (Diog. Laerc., VII 4). Y en algún pasaje, en la obra de Eliano, se nota esa indistinción acerca de la especie humana: las mujeres desprecian a sus maridos cuando éstos empiezan a envejecer y dirigen su mirada hacia los jovencitos; y los maridos beben los vientos por las jovencitas sin hacer caso de sus mujeres que traspasaron ya la adolescencia; y esto lo contrapone al

86 Cf. Ael., NA III 42, el calamón tiene un gran concepto de los deberes conyugales y lo detesta hasta tal punto que prefiere matarse antes que soportarlo; VII 25; VIII 20; X 1; XI 15; XV 14.

87 Cf. Ael., NA III 47, el camello que comete el incesto engañado por el hombre y luego el animal se venga matándolo y se arroja a un precipicio, en contraposición con el proceder de Edipo, dice Eliano, que siguió ocasionando más desgracias; otros casos de incesto, IV 7, 9, 12; VI 39. 
actuar de los alciones hembra que transportan sobre su espalda a los machos debilitados por la vejez (VII 17). Sin embargo, ni la Estoa ni Eliano parecen tener en la misma consideración a la mujer que al hombre; Eliano lo manifiesta con algunos juicios personales; así se expresa dando un carácter general a su opinión: "parece que también entre los irracionales la naturaleza otorgó preeminencia al macho sobre la hembra" (VII 26; XI 26). Al tratar del gallo y de su canto, dice que incuba los huevos, si se muere la gallina, y saca los polluelos, pero lo hace en silencio, y no canta por una extraña y misteriosa razón, y comenta el autor: "pues me parece que lo haga porque está convencido de que entonces está realizando las labores propias de una hembra y no de un macho" (IV 29). En la dramática historia que cuenta, brevemente, de Lenila y sus hijos - familia perteneciente al orden senatorial romano - se descubre una dura crítica contra las mujeres libres que llegan a ocasionar con la calumnia la muerte incluso de sus hijos; y aprovecha la ocasión para atacar la alta sociedad romana de su tiempo, y resaltar la degradación moral y el comportamiento injusto de los magistrados (VII 15). Por último, quiero vislumbrar un juicio nada favorable sobre la mujer en el pasaje que toma de la Odisea, en que habla de la droga que Helena mezcla con el vino de Telémaco para ayudarle a olvidar las penas por su padre (Ulises); Eliano considera ese remedio - parece que de manera despectiva como "un don de una mujer", capaz de hacer olvidar los infortunios sólo durante un día (IV 41).

Destaca, en general, el interés colectivo sobre el individual. De fondo está sustentándolo la teoría de la $\sigma 0 \mu \pi \alpha ́ \theta \varepsilon 1 \alpha$ ('simpatía') de todas las cosas, muy en boga de nuevo - se origina en los filósofos presocráticos -, en los primeros siglos de nuestra era; según la cual, todo está interrelacionado; entre los seres del cosmos se dan atracciones y repulsiones; existe una afinidad mutua entre todas las cosas de la naturaleza ${ }^{88}$. Los estoicos acataban este principio científico-filosófico, que se convierte para ellos en una creencia religiosa, sustanciada en el $\lambda o ́ \gamma o \varsigma$ cósmico, en la noción de "providencia" ( $\pi \rho o ́ v o 1 \alpha)$ y en la convicción de que el todo debe estar por encima de la parte. También lo expresa Eliano en varios pasajes (V 11; V 10; I 60; V 15; I 9); esa interinfluencia se ejerce a nivel cósmico: del sol y de la luna en numerosos seres (IV 43; IX 6; X 16; XV 4); lo testimonia en

88 Cf., mi ponencia «Religión, superstición y ciencia en la antigüedad griega tardía», en Creencias y supersticiones en el mundo clásico y medieval, XIV Jornadas de Estudios Clásicos de Castilla y León, coord. M.-A. Marcos Casquero, León, 2000, pp. 77-78. 
su creencia en el astro solar como una divinidad (V 39). La "simpatía oculta" unía a los planetas con los reinos vegetal, animal y mineral. Toma gran auge en estos siglos la astrología y la magia ${ }^{89}$. Se observa su aceptación de la mención de hechizos y en la explicación de circunstancias debidas a la magia (I 29; I 35; I 36; I 37; I 38; I 39; I 54; II 14; VI 33). Descubre un instinto adivinatorio en los animales (I 48; II 46; II 51; IV 48; IV 60; VI 16; VII 45; VIII 5); previenen meteoros (III 14; V 52; VI 24; VII 7; VII 8); la presencia de algunos trae mal agüero (X 34; X 37; XI 19; X 34); Eliano admite hechos debidos a causas extrañas e inexplicables (VIII 28; XI 40; XIII 13; XVI 16; XVII 15), y se infiere del texto sus creencias supersticiosas (III 9; XI 18; XVI 16; XVII 12). Ese interés de que lo de todos predomine sobre lo del individuo, considera que lo ejemplifican bien los animales, su sociabilidad y jerarquía (X 8) y llegan a tomar, incluso, medidas prácticas ante el aumento de número de su comunidad (V 13, las abejas).

Resalta con frecuencia, contra el parecer de los estoicos, la gran paradoja consistente en que los animales irracionales se muestran como seres inteligentes en contraposición a los seres humanos racionales que no lo demuestran. Esa crítica la expresa de manera abierta contra Cleantes de $\mathrm{Aso}^{90}$. Siguiendo la autoridad de Eudemo, dice que los animales están privados de razón pero tienen un instinto natural y no aprendido

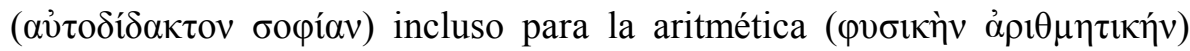
(IV 53; VII 1; XI 12); muestran capacidad de raciocinio y memoria (VI 59; XVI 10; IV 35; VI 10; XI 14); en numerosos pasajes alaba la inteligencia innata de los animales (II 11; II 18; II 49; IV 44; IV 53; V 11); expresiones

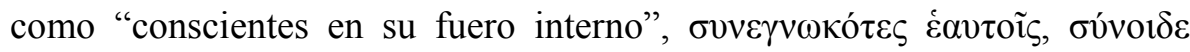

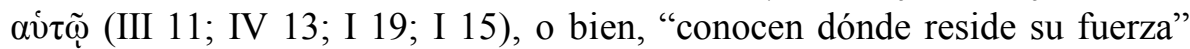
(IX 40) indican la atribución, por parte del autor, de cierta capacidad mental; no es infrecuente, en ellos, el dominio de técnicas y habilidades

89 En el siglo II, Claudio Ptolomeo es autor del Tetrabiblos, obra con la que trata de dar una base científica a la práctica de aquel tiempo astrológica y mágica; y escribe, asimismo, el tratado científico de la Harmonía dentro del ambiente filosófico del neopitagorismo, escuela que, a través del estudio de la aritmética, geometría, astronomía y harmonía, llega a una concepción del cosmos ordenado por un lógos universal divino. La ciencia no está reñida con la práctica astrológica ni con la magia.

90 Cf., Ael., NA: VI 50: al contar la historia de la presencia de Cleantes ante un comportamiento curioso de las hormigas dice: "Cleantes de Aso fue obligado, contra su voluntad y en oposición a los argumentos sostenidos por él con gran vehemencia y fuerza, a deponer su actitud y admitir que los animales no carecen de razón”. 
determinadas (V 26; VII 21; VII 45; VIII 9; IX 4).

Para los estoicos, la característica que distingue, sobre todo, a los seres humanos de los irracionales es la posesión del lenguaje; Eliano, aunque está de acuerdo en este punto de vista, no se cansa de mostrar, sin embargo, las cualidades de los animales que los acerca a esa facultad humana de comunicarse de manera abstracta ${ }^{91}$.

Gran sensibilidad y don natural demuestran los irracionales para aprender la música, el ritmo y el canto ${ }^{92}$. Capítulo especial, por su amplitud y detalle, es el que dedica a expresar aquello de lo que es capaz el elefante; "es admirable, dice Eliano, que un animal, desprovisto del lenguaje articulado comprenda el ritmo y la melodía, que sepa seguir pasos de danza sin hacer errores cumpliendo las exigencias de las lecciones recibidas; (...) todo esto, concluye, son dones otorgados por la Naturaleza y a la vez de una peculiaridad sorprendente" ${ }^{93}$.

En la medicina pueden superar, dice Eliano, al hombre, en técnicas medicinales determinadas y dándoles a conocer ciertos medicamentos ${ }^{94}$.

La amistad es sentimiento muy importante en la vida social, tanto para los estoicos como para los epicúreos en la época romana. Eliano presenta este sentimiento en los animales en contraposición al de los seres humanos, y siempre les aventajan aquéllos; se queja de que el término amistad no significa nada en boca de los hombres (II 42; III 46; V 48; VI 2). Muy extendida, dice Eliano, es la solidaridad en el mundo animal frente al

91 Cf., Ael., NA: comprenden el lenguaje humano (II 31 y en XII 6, el cisne; IV 24 y XI 25, el elefante; I 18, el delfín; II 51, el cuervo; III 1, el león; IV 46, 54), incluso parecen conocer las letras (II 11), el peculiar tono de sus voces puede advertir de algo (I 18; IV 16, 21, 29; I 20, 29, 43).

92 Cf., Ael., NA: II 16 y XII 44, los elefantes; IV 42, el francolín y la gallina de Guinea; V 13, las abejas; XII 45, los delfines; XV 25 y XII 44, las yeguas; XVII 18, la pastinaca; y otros pasajes: V 51; VI 19, 31, 32; XI 1; XII 46; XVII 22.

93 Cf., Ael., NA II 11. Los animales son especialmente dóciles y aventajados en recibir enseñanzas del hombre, II 11; III 1; IV 24, 26, 42; V 13; VI 2; VII 27; VIII 4; X 10; XII 23; XIII 9; XVI 25.

94 Cf., Ael., NA: el ave ibis enseñó a los humanos los clísteres y los purgantes (II 35); medicamentos conocidos por los animales (I 37, 42, 54; II 18, 35, 43; III 5, 14; IV 36, 41; V 3, 46; VII 14; VIII 12; IX 31; XII 32; XIV 2, 4; XVI 39; XVII 32). O bien proporcionan a los hombres diversos beneficios (I 42, 57; II 8, 42, 57; XVI 31), y colaboran con ellos (II 8, 42; $\mathrm{XIV}, 1$ ); los hombres imitan las técnicas de los animales (I 59). 
comportamiento humano (V 6), así como las muestras de afecto ${ }^{95}$.

Y en la Naturaleza se da un grado mayor en la profundidad de la amistad: si entre los hombres es el hijo quien venga a su padre ofendido o muerto, en la naturaleza es el amigo, aún no siendo un congénere, el que actúa como un hijo (IV 45). Con referencia al amor hacia los de su especie, los irracionales lo muestran de manera constante y obran de modo diferente a los hombres; Eliano, con desesperanza, cuenta la actuación de los delfines ante uno de los suyos que fue capturado y herido, acude la manada en su ayuda y como signo de protesta, logran que se le libere y se hacen cargo del herido, y escoltándolo como si se tratara de un pariente, se marchan; y sigue Eliano con la siguiente exclamación "¡Rara vez un ser humano aporta a un pariente - sea hombre o mujer - en la desgracia su desvelo y preocupación!" (V 6) ${ }^{96}$.

Muestran agradecimiento hacia aquellos que les hacen un $\operatorname{bien}^{97}, \mathrm{y}$ comenta Eliano, de nuevo, con enorme ironía y clara denuncia: "en cambio el hombre, animal dotado de razón y que tiene el privilegio del intelecto, que obtuvo el sentimiento del honor y en quien se supone sonrojo, puede llegar a ser enemigo implacable de su amigo, y cuantos secretos le fueron confiados por quien tenía fe en él, por un motivo muy insignificante y casual, los escupe pérfidamente para perdición de quien había confiado en él"98.

95 Cf., Ael., NA: A los animales les agrada la convivencia con los compañeros y hacer amistades (V 28), aunque también tienen enemistades (I 32; III 7; IV 5; V 48). Sienten gran afecto hacia los hombres (I 6, 8; II 6, 42; VI 63; VIII 3; X 48; XI 14; XII 21); de manera especial por sus amos (II 40; III 46; VI 25, 44; VII 10, 40; X 41); parecen enamorarse de los seres humanos (I 6; IV 54, 56; V 29; VI 15, 17, 29; VII 43; XII 37). En algunos casos, los hombres les honran por su conducta (VII 38); y se enamoran de ellos (IV 8; VI 2).

96 Es muy grande, también, el afecto que los delfines muestran hacia su prole, imitados en esto también por otros animales; los elefantes por ejemplo se sacrifican para salvar a sus pequeños (I 18). Y añade Eliano, en polémica, probablemente, contra Crisipo o Posidonio: "así pues, son ridículos aquellos que ponen en duda que el cariño de los elefantes hacia su prole es natural" (IX 8); también el de la vaca por su ternero (XIV 11); hay otros numerosos ejemplos de muestra de cariño y cuidados hacia su prole (I 14, 16, 17, 18, 37; II 40; IV 52; VI 9, 48; IX 18; X 8; XI 14).

97 Cf., Ael., NA: II 6; III 21; IV 44; VIII 22; X 48; XVII 37; que son agradecidos lo testifican, en Egipto, los gatos, las mangostas, los cocodrilos y hasta los halcones (IV 44).

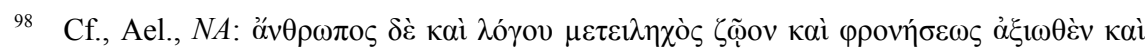

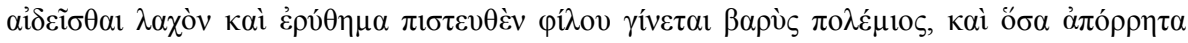

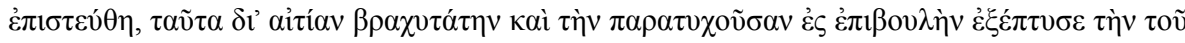

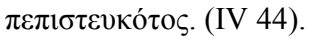


En ese tono desvelador y crítico de los defectos humanos de su tiempo, hace un comentario, al tratar de los parásitos de los peces, que pone en evidencia uno de los grandes males sociales: "La rémora y el delfín son, a mi juicio, amigos y compañeros de rancho, ya que la adulación y otros vicios los conoce el hombre, pero los irracionales los ignoran", y pone, con ironía delatora, ejemplo de adulación, el de Clísofo que se tapó un ojo con una venda, por congraciarse con Filipo que había perdido uno en el asedio de Metone (IX 7) ${ }^{99}$.

Los animales muestran precaución contra el enemigo (I 37; VI 4; VI 21), astucia, sagacidad (VI 47; VII 26; XIII 11). Dan ejemplo de valentía (V 11; VI 1; VIII 17); de previsión, esfuerzo, laboriosidad, y con dura acusación, por parte de Eliano, contra la holganza de los hombres ${ }^{100}$; destacan también por su frugalidad, autodominio y moderación en la comida frente a los seres humanos (VI 13; VIII 9). Experimentan otros muchos sentimientos ${ }^{101}$ y son muy pocos los que son malos y siempre en menor grado que los humanos ${ }^{102}$.

Un aspecto de cierto interés, dada la valoración que Eliano otorga a los animales y el conocimiento que tiene de sus cualidades, es analizar el papel que el vegetarianismo representa en su obra. Los estoicos de la época romana, como ya hemos dicho arriba, aprueban el consumo de la carne de

99 Situada en la costa noroeste del golfo Termaico, el asedio tuvo lugar en el a. 352 ó 354 a. C. (cf. Plu., Quaest. Graec. 293 B). Sobre este parásito, adulador de Filipo, cf., también, Ateneo, VI 248 D-E. En otro pasaje, el parasitismo en los animales lo considera como una alianza y mantenimiento de paz con los que les pueden ser útiles; se despojan, dice, de su ferocidad ante la conveniencia (III 11), pero no por la adulación.

100 Cf., Ael., NA I 9 y IV 43; I 10, 21; II 25, 39; V 12, 13; VI 49.

101 Cf., Ael., NA: Sienten pena, y de manera más duradera, por sus hijos muertos o heridos (I 18; VII 43; X 41); así como placer y dolor (I 18, 19, 38; II 41); expresan sentimientos de aflicción y vergüenza (en III 1, el león de Mauritania que convive y se cría con los mo-

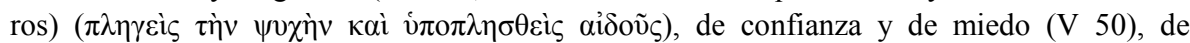
añoranza (X 47).

102 Cf., Ael., NA: para Eliano, los animales malos son muy raros y son menos malos que los hombres (I 54, serpientes); en igualdad con los hombres en III 2; VII 21, el mono, y lo es precisamente, cuando intenta imitar al hombre; VII 20, el lobo, igual que los hombres perversos con tal de tener dinero; I 54, el áspid, pero aún le ganan las hechiceras Medea y Circe, que matan sólo por contacto; III 19, la foca; VI 41, los ratones). Puede darse el odio entre ellos (I 32; III 7; IV 5; XII 15, el cocodrilo contra el hombre y otros animales que son su presa; en cambio, en IV 44, los cocodrilos son considerados animales agradecidos si reciben un bien). 
los animales en contraste con otros pensadores, a partir de los pitagóricos ${ }^{103}$. Eliano, en principio, critica de manera tajante el comportamiento criminal

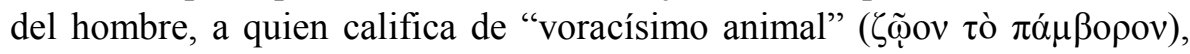
para con los delfines, a los que "no sólo no respeta la vida, sino que incluso se atreve a hacer con ellos conserva" ${ }^{104}$. Para Eliano, el manipularlos de esa manera es signo, de una conducta de los hombres mucho más criticable moralmente. Se observa en él un indicio de su sensibibilidad muy digno de ser notado, y alude de manera indirecta a la industria de salazón, muy desarrollada en el mundo romano. Rechaza la conducta de los hombres para con esos peces, por su conocimiento de la música y, gracias a este don, por ser protegidos de las Musas, y por la piedad que muestran hacia sus muertos. En otro pasaje, alaba a la abeja porque lleva una vida pura

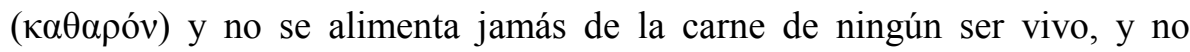
necesita para ello, dice, del consejo de Pitágoras, sino que le basta que haya flores para su alimentación ${ }^{105}$. Y dice algo similar del águila llamada "de Zeus", rapaz de discutida identificación; esta variedad, cuenta, "no prueba la

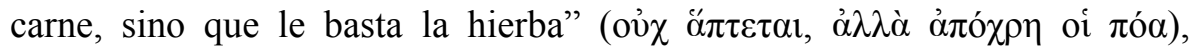
aunque no conozca la norma pitagórica (IX 10). También podría indicar algo el hecho de que cuando se refiere a la opinión común de que la carne de cerdo es la más sabrosa (IX 28), no acude, o evita mencionar una conocida cita de Crisipo, que se encuentra en otros autores ${ }^{106}$, y en Plutarco que es un autor que Eliano sigue con frecuencia, en la que se dice que los dioses dieron el alma al cerdo para conservar la carne, como se hace con la sal, y poner así algo tan sabroso a disposición de los hombres. Y comenta, en otro pasaje, cómo los iniciados se abstienen de comer ciertos peces, por razones

103 Empédocles, Teofrasto y otros, por diversos motivos, eran favorables al vegetarianismo; algunos debido a sus creencias religiosas en la metempsícosis; es interesante el tratado De abstinentia del filósofo neoplatónico Porfirio (ca. 234-300 d. C.); tratado en el que nos transmite extractos del tratado de Teofrasto, Sobre la piedad (De pietate), que no ha llegado a nosotros (Porph., ob. cit., III 5), y también textos de Empédocles (Porph., ob. cit., II 27.), y de Ovidio (Met. XV 75-175).

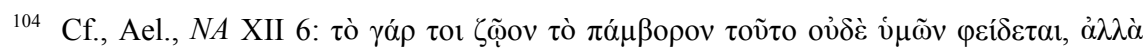

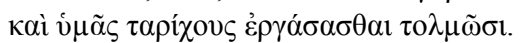

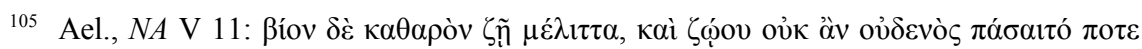

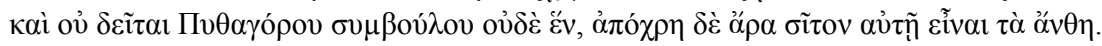

106 La citan al tratar del tema de los beneficios que aportan los animales a los hombres, o bien de criticar el alimentarse de carne. Cf., Cic., De nat. deor. II 64.160; Plin., Nat. Hist. VIII 207; Plu., Quaest. conv. 685 C; Porph., De abstinenta 3.20. Cf., también, SVF II 1154. 
religiosas (IX 65).

Son notas por las que se podría ver que el autor es favorable al vegetarianismo, sin poder afirmar, ni mucho menos, que lo practicase; no es fácil por la obra deducir de manera segura su opinión en este aspecto. Al hablar de los sacrificios, Eliano los aprueba y sostiene que los animales se ofrecen espontáneamente (XI 4; XVI 16); ciertamente, este dato hay que considerarlo dentro de su religiosidad y de la función que desempeña de sumo sacerdote. Hay un pasaje en el que describe un sacrificio de cuatro elefantes muy corpulentos, hecho por Ptolomeo Filopátor al sol, con el fin, dice Eliano, de tributar con esta ofrenda un homenaje a la divinidad, y comenta, literalmente, "o al menos él así lo creía"; pero le turbó, continúa el autor, un sueño en el que el dios le amenazaba por tan desacostumbrado y extraño sacrificio, y el rey para aplacar al dios y tenerlo propicio, hizo cuatro elefantes de bronce. Y sigue arguyendo cómo los elefantes veneran a los dioses y, en cambio, los hombres dudan de su existencia (VII 44). Por tanto, expresa ciertos reparos incluso acerca del sacrificio de animales. Con la mayor frecuencia expresa sentimientos de piedad hacia ellos, como hemos señalado arriba en las numerosas muestras de afecto y cuidados que los animales expresan, actitud que lo aleja de los estoicos, acercándolo más a los epicúreos.

Eliano, muy preocupado por la conducta moral de los seres humanos, acude a otra fuente inestimable para él de la conducta de los animales, la de la tradición fabulística; en las fábulas encontrará ejemplos de comportamiento animal para imitar y para rechazar. En algunos casos son pequeñas historias etiológicas, leyendas o fábulas noveladas conocidas por otros autores ${ }^{107}$. Otro recurso del que se vale es el del mito, como el de la Geranomaquia, XV 29. Eliano que muestra su espíritu crítico con gran frecuencia - contra Heródoto, II 53, XV 16 -, sin embargo, acoge en ocasiones además de mitos, noticias absurdas y extrañas ${ }^{108}$ que debían pertenecer al patrimonio común, y cuya fuente no provenía de la

107 Cf., Ael., NA: el leopardo y las monas, V 54; el delfín enamorado de un niño, VI 15; el comportamiento del castor, VI 34; el asno y la serpiente, VI 51; el águila y el labrador, VII 37; Lacides y su ganso, VII 41; Pirro y su elefante, VII 41; el mulo cargado de sal, VII 42; el elefante y la florista, VII 43; Androcles y el león, VII 48; la serpiente de Melitis, XI 17; el águila y el segador, XVII 37.

108 Cf., Ael., NA I 25, 28, 50, 51; II 17, 23, 31, 57; III 19; IV 48; V 16; VI 14; II 33; VI 36; XVI 17. 
observación de la naturaleza, sino muy probablemente de manuales de zoología pseudocientífica, que recogían todo lo que procedía de la tradición. Pero hay que decir que lo hace conscientemente, según él mismo expresa a propósito del toro sagrado Mnevis de los egipcios: "si alguien considera que es muy vergonzoso alejarse de las razones naturales para caer en los mitos, necio es; pues yo digo cuantas cosas se hacen con estos toros y cuantas se hicieron y lo que he oído decir a los egipcios; no eran mitos, dice, para ellos es muy odiosa la mentira" "109. Transmite la información según le llega procedente de otras culturas o de otras gentes; tal como era aceptado y creído por esos pueblos o transmitido por sus fuentes de información. En otro pasaje dice: "Yo no creo a Eudoxo, pero si otros quieren creerlo, créanlo cuando dice que ha visto, pasadas las columnas de Hércules, unas aves más grandes que un buey. Ya dije que no me convence su información, pero yo no silencio lo que he oído" "110. Además de su opinión, parece estar por encima ese afán de recoger de manera exhaustiva todo el material, como ha declarado en sus objetivos en el Prólogo. Esto le acerca a los paradoxógrafos, subgénero que tanto se desarrolló en esos siglos.

El enciclopedismo y la creación de obras de antiquaria que se encuentran en Plutarco, Ateneo, Luciano y otros, tan del gusto de la época en ese afán de recoger toda la tradición antigua, los muestra también Eliano en el material del mundo animal, y en su Varia historia. Este autor se puede contemplar dentro de esa corriente que ya viene de siglos anteriores, que tiene como objetivo primordial conservar la cultura de los siglos precedentes, introduciéndole elementos moralizadores, caracterizados por consideraciones éticas, científicas, doctrinales y literarias. De esta tendencia, que conlleva también una finalidad didáctica y de divulgación cultural, derivan los compendios y los epítomes muy variados; compuestos por la concatenación desde un punto de vista temático, o por la procedencia de la información, o por otros motivos. Asimismo, en conexión con estos objetivos nació también el género de la paradoxografía a la sombra de las grandes bibliotecas helenísticas. Conocedores de la inmensa cantidad de obras que llegaban, y cautivados por sus variados contenidos que colmaban

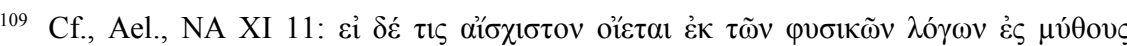

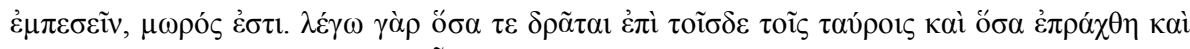

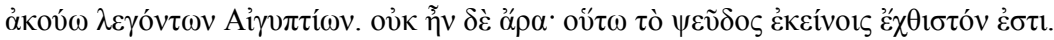

${ }_{110}$ Cf., Ael., NA XVII 14. de manera semejante se expresa también acerca de Eudoxo en XVII 19 
su afán de saber, comenzó a verse necesaria, previa lectura, una labor de criba y selección, con el fin de hacer los contenidos asimilables para un público ávido de toda clase de noticias; se entresaca y agrupa todo lo que tenga algo en común (lo maravilloso, lo científico, lo curioso, la simple anécdota, los proverbios, y otros); se recorta la noticia que procedía de unos contextos originales, donde formaba parte de un complejo narrativo histórico, científico, o cualquier otro, y pasa a formar parte de otras obras de compilación de los más variados temas ${ }^{111}$. Se divierte o enseña a las generaciones extrayendo de la antigüedad los ejemplos oportunos. No hay que perder de vista la preocupación ética y religiosa de Eliano que subyace en su afán de dar la máxima información acerca del tema animal. Se podría decir que su interés científico se ve complementado con su afán moralizante y puede aparecer incluso, al gusto de la época, dentro de su elaboración del material animal, lo extraordinario y maravilloso.

Y para terminar con este análisis vamos a mostrar qué postura toma el autor ante la muerte y si tiene alguna conexión con la opinión que acerca de ella han expresado los estoicos. Nos fijamos en dos pasajes en que toca este punto. Como hemos visto, para el filósofo estoico, lo importante es la virtud, que suele considerar como el vivir de acuerdo con la Naturaleza; todo lo demás que no depende de nosotros no debe preocuparnos y son bienes o males "indiferentes"; así la muerte debe aceptarse como un suceso natural, que no depende de nosotros. Eliano nos lo muestra en la conducta de los cisnes, cuando les llega el término de su vida; lo sobrellevan con buen ánimo, ya que han recibido de la Naturaleza el más bello don: tienen fe, dice, en que en la muerte no hay nada de triste y doloroso; en el momento final de su vida, cantan y rompen en un canto fúnebre, un homenaje a sí mismos. En cambio, los seres humanos sienten miedo de lo que ignoran y consideran la muerte como el mayor de sus males. No obstante, muestra el comportamiento de dos personas ${ }^{112}$, como modelo del que él propone ante la muerte, después de una vida ejemplar; uno, el del magnánimo héroe épico Belerofonte, celebrado por Eurípides de quien toma la cita; al morir finge hablar con su alma y dice: "fuiste siempre en vida piadosa con los dioses, socorriste a los extranjeros, y no te cansabas de ayudar a los amigos, y otras

111 Cf., para el género de la paradoxografía, entre otros, la Introducción de J. Gómez Espelosín, Paradoxógrafos griegos, Madrid, 1996, y sobre la técnica de la compilación, pp. 7-30.

112 Cf., Ael., NA V 34. 
cosas tales", dice Eliano. Y comenta a continuación, "también el cisne entona su canto fúnebre, ejecutando himnos en honor de los dioses o un relato de sus propias alabanzas como viático de su partida". El otro testimonio es el de Sócrates ${ }^{113}$ ante la muerte, quien con entereza y ánimo sereno la espera, y dice que el cisne canta no de pena sino de alegría, porque a quien le embarga el alma la tristeza y el dolor no está disponible para el canto y la melodía. La muerte, dice Eliano, libera de males; es el mejor olvido de los infortunios, pues es un olvido eterno. Hay un capítulo donde Eliano se expande en el comentario y deja ver su opinión acerca del significado de la muerte para el ser humano que está me parece muy acorde con la doctrina estoica (IV 41): al tratar del excremento del ave díkairon ${ }^{114}$, dice que, disuelta una mínima cantidad en la bebida, produce una muerte semejante a un sueño muy dulce e indoloro, como aquel que los poetas gustan de llamar "que relaja los miembros" y "suave"; y sigue, "pues también la muerte puede estar libre de dolor y, por esto, ser muy dulce a los que la desean" 115 . El autor después de comparar este remedio que es indio, según dice, con otro egipcio, gracias al cual Helena hizo olvidar a Telémaco por un día su gran pena por la suerte incierta de su padre ${ }^{116}$, valora la gran diferencia que hay entre suprimir los pesares durante un día y proporcionar un olvido de los males que dura para siempre. "La droga egipcia", sigue diciendo, "era el don de una mujer, la otra de un pájaro o bien de la misteriosa Naturaleza que libera de unas cadenas en verdad las más pesadas por medio del mencionado auxiliar". Los indios, añade, "tienen la suerte de poseer un medio que los libera de esta prisión terrena cuando quieran" ${ }^{117}$.

113 Cf., Platón, Fedón, 84e.

114 Parece que el díkairon (los griegos lo llaman dikaion) se trata no de un ave, sino del insecto, Scarabaeus pilularius o escarabajo pelotero. Y el "estiércol" era quizás una preparación resinosa de hachís, según nota a la traducción de J M. Díaz-Regañón López, ob. cit., I, p. 202. Cf. D' Arcy Thompson, A Glossary of Greek Birds, Londres, 1936, s. v. dikaion.

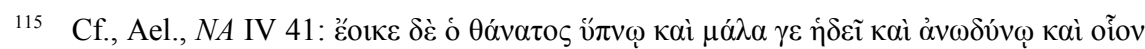

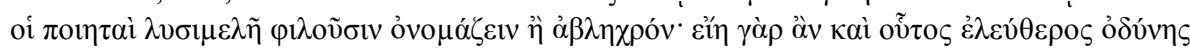

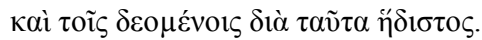

116 Se refiere al pasaje de la Odisea IV 219-232, donde Helena mezcla una droga, tal vez opio, en el vino de Telémaco, "con la que quedara por todo aquel día curado de llantos" (223).

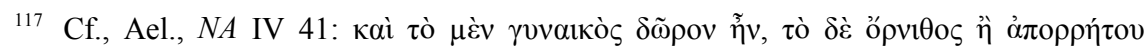

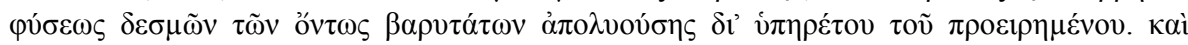

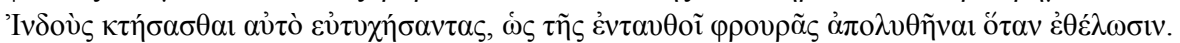


Esta idea de considerar este mundo como una cárcel para el ser humano, de manera semejante a la prisión del cuerpo para el alma, de las que se desea salir cuanto antes, adelanta un pensamiento que se encuentra en el cristianismo $^{118}$.

En fin, es un antropocentrismo el de Eliano sui generis, se aleja del de los estoicos, ya que él lo comparte con un gran sentido de compasión hacia los animales, se podría decir, con una marcada peculiar "zoofilia", enteramente convencido. Cuando se contempla el conjunto de su obra sobre los animales, no puede dejar de observarse que su consideración hacia estos seres vivos es muy alta, y es proporcional, no cabe duda, a su enorme pesimismo acerca del ser humano; la vida de los seres irracionales le merece tanta estima, se diría que más que la de los humanos, ya que estos últimos ejercen su capacidad de actuar libremente, sin ser aparentemente responsables de las propias acciones; la posesión de la racionalidad, rasgo definitorio como seres humanos, queda para Eliano en entredicho cuando se sigue su comportamiento. Con este análisis, llegamos a un Eliano que en verdad se aleja del estoicismo y se acerca más a la doctrina cínica y epicúrea. No obstante, una nota significativa de su concepción general de los seres vivos es acorde con los estoicos, es al afirmar que el fundamento que asegura la vida al ser más grande es el ser más pequeño. Este pensamiento de Eliano nos lleva de nuevo a su acercamiento a la doctrina moderna acerca de la cadena natural entre los seres vivientes que forman un engranaje y una interdependencia natural de todos.

\section{Planteamientos antiguos y modernos sobre la consideración moral de los animales.}

Eliano, con una sensibilidad propia de la sociedad en la que vive y con un afán compilador de todo lo anterior en el tema de los animales, presenta a éstos como ejemplo de conducta acorde con la ley natural cósmica universal; trata de llamar la atención, acusar o exhortar, ante la decadencia moral, la irreligiosidad, la indiferencia hacia los valores tradicionales que observaba en los seres humanos de su tiempo. Como sumo sacerdote, es - y deducimos que con conocimiento de causa -, particularmente sensible ante el

118 Cf., entre otros, «Influjo de la filosofía griega en los pensadores cristianos» por J. M. Blázquez, en la obra de Vv. Aa., Cristianismo primitivo y religiones mistéricas, Madrid, 1995, pp. 227-234. 
espectáculo de desmoralización que presentaba la sociedad greco-romana en la época imperial. Al presentar y alabar las cualidades de los animales, exalta la providencia divina con su poder racional y cósmico sobre todas las criaturas. Deja en evidencia el mal proceder de los humanos, seres libres, que no realizan su fin propio, dentro de la ley de la Naturaleza, atrincherándose en leyes positivas, contingentes y vanas al ser los propios hombres quienes las transgreden.

Los estudiosos modernos, a su vez, indagan y presentan en sus investigaciones el lugar que ocupan los animales en la moral y el derecho de las sociedades industrializadas ${ }^{119}$. Existe una legislación que se ignora, dicen, de manera consciente por los inconfesables lucros que quedan en entredicho y con la amenaza de desaparecer. Por razones bien diferentes, los antiguos y los modernos incluyen a los animales en la comunidad moral.

A. Leopold, quien supo unir personalmente, junto con sus cinco hijos e hijas, a lo largo del siglo veinte, una carrera científica con un activismo ecológico, escribió lo siguiente: «Toda ética desarrollada hasta hoy se basa en una sola premisa: que el individuo es miembro de una comunidad de partes interdependientes (...). La ética de la tierra simplemente ensancha las fronteras de la comunidad para incluir suelos, agua, plantas y animales, o de manera colectiva, la Tierra. (...) Una ética de la tierra cambia el papel del homo sapiens de conquistador de la comunidad terrestre por el de mero miembro y ciudadano de ella. Ello implica respeto hacia los otros miembros y también hacia la comunidad como tal».

Esa ampliación de la ética que trata de la relación humana con la tierra y con los animales y plantas que crecen en ella, dice A. Leopold, «es, si no me equivoco, una posibilidad evolutiva y una necesidad ecológica». Este autor parece seguir una idea semejante que la que en el fondo defendía $\mathrm{Ch}$. Darwin, aunque este autor proponía la expansión del círculo de la ética como explicación del surgimiento histórico del comportamiento moral; ya

119 Cf., entre otros, Henry. S. Salt, Los derechos de los animales, ed. J. Mosterín, trad. de C. Martín y C. González, Madrid, 1999, con capítulos como «El principio que reconoce los derechos de los animales», «El caso de los animales domésticos», «El caso de los animales salvajes», «La matanza de animales como alimento», «Caza deportiva, o matarifes de afición», «La tortura experimental»; con una bibliografía comentada del propio autor, pp. 121-145; y bibliografía básica selectiva, pp. 147-148. Aldo Leopold, Una ética de la tierra, trad. por I. Lucio-Villegas y G. Riechmann, ed. J. Riechmann, Madrid, 2000, con introd. del mismo editor, pp. 7-35. S. Muñoz Machado, Los animales y el derecho, Madrid, 1999. 
veía, sin duda, cómo la compasión hacia los animales inferiores parecía ser una de las últimas adquisiciones morales ${ }^{120}$. Hay que decir que, con otro planteamiento científico-filosófico y moral, este desarrollo de la ética, en sentido global, ya está expresado por los primeros formuladores de la teoría

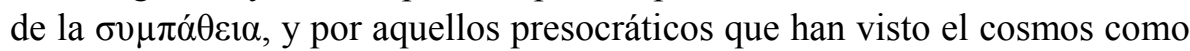
un todo organizado e interrelacionado, al que le dieron el carácter de divino, racional y eterno. Y más tarde, Aristóteles con su deseo y plan de buscar las causas y dar explicaciones de todo, es decir, de construir una ciencia que se entronca con una explicación científica y filosófica del cosmos, todo ordenado y orientado hacia su telos divino, el Bien o la Belleza, establece los cimientos, bien asentados, de las investigaciones e inquietudes morales modernas de la cultura intelectual de Occidente. La explicación de la acción animal para el desarrollo de la ética y la moral, y la que podríamos llamar "compasión" hacia los animales en algunos de sus tratados, como hemos visto, le hace mucho más próximo y auténtico antecedente de las modernas investigaciones que han ido avanzando de un antropocentrismo a un biocentrismo $^{121}$.

El modelo clásico de la acción racional toma una nueva formulación en la teoría matemática de la decisión; y recibe una crítica de parte de John Searle, sobre la que incidimos anteriormente, para quien el libre albedrío o la posesión de un lenguaje son elementos fundamentales cuando se quiere dar explicación de nuestra toma racional de decisiones, pero no los únicos; según Searle, la racionalidad es un fenómeno biológico y, por tanto, un fenómeno universal ${ }^{122}$.

En el mundo antiguo ya los hombres utilizaron a los animales para aprovecharse de ellos, como diversión, como producción de alimentos, para consumo de sus carnes, como explotación con carácter lucrativo. Y también hubo intelectuales, filósofos, científicos o literatos que tuvieron una cierta percepción ecológica, pero siempre en un ambiente muy restringido. La sociedad no estaba preparada con los medios adecuados para estimular

120 Tomo las citas de la Introducción de J. Riechmann a la obra citada de Leopold, pp. 25-26.

121 Sobre el sentido y matizaciones de significado con que se emplean estos términos, véase, entre otros, «Antropocentrismo y biocentrismo en sentido moral», pp. 27-29, de la Introducción citada de J. Riechmann; cf. también del mismo autor, Un mundo vulnerable. Ensayos sobre Ecología, Ética y Tecnociencia, Madrid, 2000.

122 Cf., J. R. Searle, ob. cit., p. 19. 
actitudes y comportamientos de respeto hacia los animales inferiores y el medio ambiente ${ }^{123}$. Y las ideologías y creencias del estoicismo y cristianismo, muy enraizadas en la tradición occidental, que postulaban que la racionalidad constituía la base de la moral, han anclado de manera muy fija la defensa a ultranza del antropocentrismo. También Eliano se mantiene en él, pero de manera simultánea intenta mostrar las cualidades de los animales como instrumento útil para adoctrinar y moralizar a los seres humanos, que quedan a gran distancia, según su opinión, de la actuación recta de los animales, debido a la posesión del hombre del libre albedrío.

Actualmente, se admite, incluso por los defensores del antropocentrismo, que los animales merecen cierto respeto moral, y que los seres humanos tienen ciertas obligaciones morales para con ellos; pero siguen considerando que, por la superioridad de los seres humanos, tienen éstos derecho a tratar la naturaleza a su conveniencia. Sin embargo, algo se está consiguiendo y de una manera explícita lo indican las últimas publicaciones. Declaraciones como la que sigue muestran los nuevos planteamientos a nivel general: «Si afirmamos el parentesco evolutivo de los seres humanos con todos los demás seres vivos, el hecho de que la biosfera es nuestro espacio vital común para todas las especies, y sobre todo que el especieísmo es moralmente inaceptable, podrá parecer plausible una nueva ampliación de la comunidad moral hasta incluir, por lo menos, a los animales superiores cuyas capacidades intelectuales y emocionales se hallan al mismo nivel que las de los niños pequeños o de los humanos discapacitados. Se hallan en esta situación, por lo menos, los primates (...). También parece plausible - a tenor de nuestra argumentación zoocéntrica benthamiana - dar un paso más, hasta incluir dentro de la comunidad moral a todos los seres sintientes: o sea, por lo menos los animales.(...) Ciertamente no todos los animales son racionales, ni capaces de lenguaje: pero en cambio compartimos con ellos la capacidad de padecer dolor y sufrimiento, y en general la capacidad de sentir ${ }^{124}$.

123 Es interesante, la breve monografía, Ecología en la Antigüedad clásica, por J. F. Rodríguez Neila, en Cuadernos de Historia, Madrid, 1996; con bibliografía muy útil en pp. 67-68; apartados como «Primeras ideas ecológicas griegas», «El lúcido análisis ecológico de Platón», «Aristóteles y Teofrasto», «El determinismo medioambiental de los romanos», y los capítulos «Los problemas medioambientales» y «Cuestiones de 'ecología urbana'», despiertan gran interés y estimulan a investigaciones más amplias.

${ }^{124}$ Cita del c. IV, escrito por Riechmann, p. 140, del libro de J. Mosterín, Jorge Riechmann, Animales y ciudadanos. Indagación sobre el lugar de los animales en la moral y el derecho de las sociedades industrializadas, Madrid, 1995. Con bibliografía y algunas 
La obra de Mosterín y Riechmann es un estudio profundo en el que se va descubriendo el lugar que ocupan los animales - y el que deberían ocupar en las sociedades industrializadas, que invita a un debate social más amplio; presenta un enfoque científico, jurídico, moral, realista y conveniente para nuestra sociedad; se puede considerar como una formulación válida de "zoofilia racional" moderna. La dirección hacia donde se camina en la actualidad, en un sentido más general, la señalan las últimas investigaciones. Los estudios y progresos realizados en la etología y la neurofisiología vienen mostrando cada vez más estructuras y mecanismos comunes a los animales superiores, y especialmente a los mamíferos. La sociobiología ha descubierto determinados rasgos compartidos por todo tipo de sociedades (animales y humanas). Los avances últimos en la lectura del genoma humano han aunado, o aproximado más, y confirmado las semejanzas biológicas de los humanos con el resto de los animales. Se observa cómo el antropocentrismo se fue desplazando y dejando de ser considerado el ser humano como el centro del cosmos. Se fue trasladando del ámbito astronómico y del biológico, pasando por el psicológico, para integrarse en una cosmicidad de todas las ciencias que lleva a una compresión global de todo lo existente, y el ser humano es considerado y estudiado en paralelo con el resto de los seres que constituyen el $\operatorname{cosmos}^{125}$.

direcciones de interés, pp. 227-245, con los anejos «Asamblea de filósofos», pp. 247-300, y la «Declaración universal de los derechos del animal», pp. 302-304. Capítulos muy interesantes: «Animales humanos y no humanos en un contexto evolutivo» (Riechmann), «El dolor de los animales» y «La muerte de los animales (Mosterín), «Razones para incluir a los animales en la comunidad moral», «Los experimentos con los animales», «La complejidad del concepto de persona», «La dimensión jurídica: ¿derechos para los animales?» (Riechmann).

125 Cf., J. Mosterín, ob. cit., p. 223. 